Journal of Southeast Asian

\title{
Cross-Linguistic Analysis of Vietnamese and English with Implications for Vietnamese Language Acquisition and Maintenance in the United States
}

Giang Tang

University of Minnesota, tangx098@umn.edu

Follow this and additional works at: https://docs.lib.purdue.edu/jsaaea

Part of the Asian American Studies Commons, Education Commons, and the Linguistics Commons

\section{Recommended Citation}

Tang, Giang (2007) "Cross-Linguistic Analysis of Vietnamese and English with Implications for Vietnamese Language Acquisition and Maintenance in the United States," Journal of Southeast Asian American Education and Advancement. Vol. 2 : Iss. 1, Article 3.

DOI: $10.7771 / 2153-8999.1085$

Available at: https://docs.lib.purdue.edu/jsaaea/vol2/iss1/3

This document has been made available through Purdue e-Pubs, a service of the Purdue University Libraries. Please contact epubs@purdue.edu for additional information.

This is an Open Access journal. This means that it uses a funding model that does not charge readers or their institutions for access. Readers may freely read, download, copy, distribute, print, search, or link to the full texts of articles. This journal is covered under the CC BY-NC-ND license. 


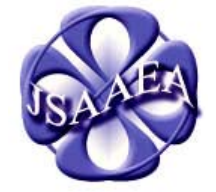

Volume 2

\section{Journal of Southeast Asian American}

Education \& Advancement

WWw.JSAAEA.org
A peer-reviewed

scholarly journal

published by the

National Association

for the Education \&

Advancement of

Cambodian, Laotian, and Vietnamese

Americans (NAFEA)

\title{
Cross-Linguistic Analysis of Vietnamese and English with Implications for Vietnamese Language Acquisition and Maintenance in the United States
}

\author{
Giang M. Tang \\ University of Minnesota
}

\begin{abstract}
Two overall goals of this paper are a) to provide a linguistic basis for promoting first language maintenance of Vietnamese in a larger United States context and b) to stimulate future research in language acquisition of Vietnamese-English speakers. This paper is divided into three sections. Section 1 discusses previous studies on first language (L1) maintenance among Vietnamese Americans. Section 2 presents a cross-linguistic comparison of Vietnamese and English across speech-sound, word, and grammatical language levels. A cross-linguistic analysis may help educators better understand speaking patterns of Vietnamese American students. Based on this cross-linguistic comparison, Section 3 presents potential bi-directional interactions between Vietnamese and English within an individual speaker. These predictions are intended to provide a framework for future empirical studies related to bilingual development.
\end{abstract}

Sociologists have documented a pattern of shift in relative language dominance from the first language (L1) to the second language (L2) of immigrant populations that occurs within three generations of arrival to the United States (Fishman, 1972; Veltman, 1983). It has been found that the grandchildren of immigrants tend to shift toward English monolingualism and may not be able to speak the language of their grandparents. This three-generation model of language shift was documented among European immigrants of the $19^{\text {th }}$ and early $20^{\text {th }}$ centuries, and continues to occur in contemporary immigrant populations from Latin America and Asia (Alba, Logan, Lutz, \& Stults, 2002).

Many studies have shown that immigrant children who speak their parents' language as well as English fluently are more likely to succeed academically than children who become monolingual English speakers (see Schmid, 2001, for review). In a study of high school students from immigrant families, Feliciano (2001) found that bilingual students were less likely to drop out of school than their English-only speaking peers. Rumbaut (1995) and Stanton-Salazar and Dornbusch (1995) found that bilingual students who are fully proficient in both English and another language had better grades and higher academic success than their monolingual English-speaking peers. In addition, maintenance of the immigrant language provides a critical means for transmitting cultural

\section{@)}

SOMERIIGHISRESERVEDReaders are free to copy, display, and distribute this article, as long as the work is attributed to the author(s) and the Journal of Southeast Asian American Education \& Advancement, it is distributed for non-commercial purposes only, and no alteration or transformation is made in the work. More details of this Creative Commons license are available at http://creativecommons.org/licenses/by-nc$\mathrm{nd} / 2.5 /$. All other uses must be approved by the author(s) or JSAAEA. 
values across generations and within one's ethnic community, which in turn promotes emotional and social balance in children's self-perception and identity (Kohnert \& Derr, 2004; Wong-Fillmore, 1991).

One way educators can promote home language maintenance while helping students acquire the majority language (English) is to better understand how languages develop and what factors may facilitate or hinder this process. The purpose of this paper is to establish a linguistic basis for future investigation of language learning patterns in individuals who speak Vietnamese as a first or home language (L1) and learn English (L2) shortly after. A clearer understanding of how children learn two languages may promote L1 maintenance as well as L2 learning among Vietnamese Americans through the creation of appropriate educational materials and resources.

This article is divided into three sections. Section one addresses the issue of language maintenance, which is operationally defined as L1 preservation across generations. Previous studies on the language maintenance of Vietnamese Americans as well as social ramifications of L1 use and disuse are presented. The studies emphasize the importance of maintaining L1 while learning L2 to promote strong social identification and overall well-being. Section two presents a cross-linguistic comparison of Vietnamese and English across the language levels of phonology (sound), lexical semantics (word meaning), and morpho-syntax (grammar). This cross-linguistic comparison provides the background for section three, which posits potential bidirectional language interactions between Vietnamese and English within an individual speaker. There has been little to no research on the language characteristics of Vietnamese-English speakers. Predictions of within-speaker cross-linguistic interactions are intended to provide a framework for future empirical studies in the areas of language acquisition and bilingual development of Vietnamese-English bilinguals.

\section{Language Maintenance Among Vietnamese Americans}

\section{Social Issues}

Although there were small numbers of Vietnamese in the United States in the 1950s and 1960s, the large Vietnamese presence began in 1975. According to the $2000 \mathrm{U}$. S. Census (Reeves \& Bennett, 2004), there are an estimated 1.12 million Vietnamese in the United States, making this group the fourth largest Asian American population following Chinese, Filipinos, and Asian Indians. Within the past 30 years, there have been various studies on Vietnamese socialization, adaptation to the United States, and language maintenance and shift (Bankston \& Zhou, 1995; Chung, 2000; Luong, 1990; McDonald, 2000; Nguyen, Shin \& Krashen, 2001; Pham, 1990; Young \& Tran, 1999; Zhou \& Bankston, 1994, 1998, 2000).

In the field of sociology, researchers have used survey and ethnographic methods to underscore the importance of maintaining the home language as a means to remain connected to one's family and community, to support a strong social identity, and to promote high academic success. Zhou and Bankston (1994, 1998) found that the Vietnamese students of eastern New Orleans who were more integrated into their ethnic community demonstrated higher academic achievement than those who were not. The level of integration into the Vietnamese community was based on self-reported measures 
of speaking Vietnamese at home, ability to read and write in Vietnamese, selfidentification as Vietnamese, and having close friends of the same ethnicity. Factors such as the adherence to traditional family values, commitment to a high work ethic, and the level of integration into the ethnic community all had significant effects on academic success.

Bankston and Zhou (1995) found a strong positive linear relationship between Vietnamese literacy and high academic achievement in English as well as between proficiency in spoken and written Vietnamese and orientation toward higher education in the majority English-speaking community. Of the students surveyed, the ability to read and write in Vietnamese was associated with a strong sense of social identification. Students who were literate in Vietnamese as well as English were more likely to place a high importance on college attendance, to spend more time on homework, and to receive high grades in school. The researchers suggested that the positive contribution of bilingualism to high academic performance was both of a cognitive transference (e.g., transfer of reading or decoding skills from Vietnamese to English) as well as a social transference of work habits and attitudes.

In contrast to the academic success reported in Vietnamese students with high levels of integration into their ethnic community, Zhou and Bankston (2000) found disproportionately high dropout levels and delinquency among less integrated youth. Less integrated youth were those who were less involved in their local ethnic community and who assimilated to the "oppositional youth culture of other economically disadvantaged young Americans" (p. 54). Zhou and Bankston reported that Vietnamese adolescents ranked second highest among racial/ethnic minority groups to be in correctional facilities - 210 youths per 100,000 — which ranked this ethnicity higher than all other Asian groups. In addition, they reported the results of a national longitudinal study of adolescent health, which indicated that Vietnamese American adolescents were more prone to uncertainty, self-doubt, fearfulness, and depression than their white and black peers. Zhou and Bankston interpreted these results as feelings of rejection from the American mainstream as well as a disconnect with one's own social and linguistic community, which may directly contribute to negative self-perceptions and may indirectly contribute to the high rates of institutionalization and gang involvement. Given these results, it is clear that the issue of language maintenance is relevant to promoting balance and stability in one's own linguistic and ethnic identity alongside academic and vocational success in the broader majority English-speaking community. The preservation of one's native language and culture promotes social and mental well being of individuals that in turn benefits the larger society.

\section{Linguistic Issues Across Generations}

Several studies have documented L1 maintenance and cross-generational shift from L1 to L2 among Vietnamese Americans. Young and Tran (1999) surveyed over 100 Vietnamese parents on the language use of their families and children. These families had lived in the United States an average of 13 years, although there was a wide range of variability in the length of stay (approximately 70\% of the parents reported 6 to 20 years in the United States). Of parents surveyed, Vietnamese was reported to be the sole home language in $84.6 \%$ of homes, while both Vietnamese and English were spoken in $15.4 \%$ 
of homes. At that time, no families reported speaking only English at home. Based on parent report, $59.2 \%$ of the children spoke Vietnamese, while less than $8 \%$ spoke mostly English. Among children, Vietnamese was still the preferred language in $45.1 \%$ of families. Approximately $33 \%$ of children were reported to speak both languages, and $21.6 \%$ of children spoke only English among themselves. Given that the length of stay for the majority of families was relatively short (less than 20 years), the children in these families seemed to be learning English quickly, with a growing number of children choosing to speak English with their friends.

Based on these results, Young and Tran (1999) reported a rapid rate of shift from Vietnamese to English in this population. Language shift was defined as a decrease in the number of speakers of a language or a decrease in L1 use across domains. Examined factors relating to language shift included family income, mother's education, father's education, and length of stay in the United States. Based on survey results, length of stay appeared to be the only factor that significantly affected language shift. The longer a family stayed in the United States, the greater the shift toward English use, whether in addition to Vietnamese or solely English. Although not statistically significant, there was an additional and rather unexpected trend related to length of stay: it seemed that the longer the stay in the United States, the more parents encouraged children to retain Vietnamese. These data suggested an increased awareness of the importance of maintaining one's heritage language among families who have been in the United States for longer periods of time and who are more likely to experience a shift towards English monolingualism. Young and Tran emphasized the danger of rapid language shift and its affect on personal identity. They suggested that the children in these families who speak only English may experience feelings of ambivalence, shame, or rejection of the home language and culture, which may contribute to a lowered self concept.

Nguyen, Shin, and Krashen (2001) surveyed over 500 Vietnamese elementary school students, grades first through eighth, in the Central Valley area of California. Seventy-one percent of the students surveyed were born in the United States Of the 29\% born outside the United States, the majority (67\%) had lived in the United States for five years or more. The students were given a Likert-scale questionnaire on their perception of Vietnamese and English proficiency, language preference, and attitudes towards the maintenance of Vietnamese language and culture. Of the students surveyed, 67\% selfreported speaking Vietnamese well. In contrast, only $23 \%$ of students reported good literacy skills in Vietnamese, and 58\% reported little to no literacy skills in Vietnamese. The vast majority of these students (84\%) self-reported speaking English very well. There was a trend among students surveyed to speak Vietnamese with parents, Vietnamese and English with siblings, and primarily English with friends. When asked about student attitudes toward L1, most felt it was important to speak, read, and write Vietnamese and to maintain Vietnamese culture. They also reported that they would like to learn Vietnamese in school. In contrast to beliefs that retention of an immigrant language will inhibit the acquisition of English (L2), Nguyen et al. (2001) concluded that during the elementary school years, there seemed to be a strong trend of maintaining Vietnamese (L1) oral skills while gaining strong English (L2) skills.

According to a U. S. 2000 Census Special Report on Asian Americans (Reeves \& Bennett, 2004), approximately 93\% of Vietnamese Americans reported speaking Vietnamese as the home language. Of these homes, 31\% reported speaking English "very 
well," and 62.4\% reported speaking English less than "very well." It should be noted that these percentages reflect overall language proficiency within a household that may include multiple generations. Older generations may speak less English and may be inflating the statistic of $62.4 \%$ of limited English speakers.

Based on these studies of L1 maintenance and shift toward greater English (L2) proficiency, it appears that language use among Vietnamese Americans currently fits within the three-generation model of language shift, originally posited by Fishman (1972). Although Vietnamese continues to be spoken in the vast majority of homes, the trend to speak Vietnamese with parents, Vietnamese and English with siblings, and English with friends indicates a gradual shift towards English. In addition, low Vietnamese literacy rates reported by Nguyen et al. (2001) may become an area of concern regarding language maintenance, particularly due to the important role literacy plays in maintaining and increasing one's oral language skills.

\section{Cross-Linguistic Comparison of Vietnamese and English}

Section 1 of this article presented the social and linguistic issues related to language maintenance among Vietnamese Americans. This information was presented as the rationale of why L1 maintenance is important in the process of participating in the larger English-speaking society. Based on previous research, we now know that children of immigrants who speak their parents' language as well as English are more likely to have high academic success (Bankston \& Zhou, 1995; Feliciano, 2001; Schmid, 2001; Zhou \& Bankston, 1994; 1998) as well as have an overall stronger self-concept and social identity (Kohnert \& Derr, 2004; Wong-Fillmore, 1991).

One way educators can promote L1 maintenance is to better understand the language structures and possible interactions between Vietnamese (L1) and English (L2). This section presents a cross-linguistic comparison of Vietnamese and English across levels of phonology (speech-sounds), lexical semantics (word meaning), and morphosyntax (grammar). This cross-linguistic analysis may help educators who work with Vietnamese Americans have a better understanding of their students' language skills and error patterns. Both languages have various dialects with distinct linguistic features. Since this paper focuses on Vietnamese Americans, cross-linguistic comparisons are made between the General American English dialect and primarily the northern dialect of Vietnamese with certain features from the southern Vietnamese dialect included for comparison. The northern dialect of Vietnamese was chosen as the main comparison because it is considered the official dialect of Vietnam (D. H. Nguyen, 2001). Southern dialectal features of Vietnamese are included because of the wide use of this dialect among Vietnamese Americans.

This section begins at the phonological (speech-sound) level, in which a comparison of Vietnamese and English consonants, vowels, tones, and syllable structures are presented. Then, a comparison at the lexical semantic (word meaning) level includes a description of lexical tone in Vietnamese as well as word formation processes in both languages. Finally, features from the morpho-syntactic (grammatical) level are compared across languages in the phrase or sentence context. 
Journal of Southeast Asian American Education and Advancement, Vol. 2 [2007], Iss. 1, Art. 3

Tang - Cross-linguistic Analysis of Vietnamese and English

\section{Phonology}

A comparison of Vietnamese and English may begin at the smallest unit of language: the phoneme or speech sound. A phoneme is defined as "the smallest phonetic unit in a language that is capable of conveying a distinction in meaning" (American Heritage Dictionary, 2000). Vietnamese has three types of phonemes: tones (sometimes referred to as tonemes), consonants, and vowels. English phonemes consist of consonants and vowels; this language does not have lexical tones. Vietnamese uses tones as phonemes since a change in tone indicates a change in meaning. For example, $m a$ "ghost" and má "cheek" are two distinct words that only differ in tone, the level (không dấu) tone and rising (sắc) tone, respectively. D. H. Nguyen (2001) describes the six tones of the northern Vietnamese dialect: level (không dấu), falling (huyền), creaky (ngã), dipping-

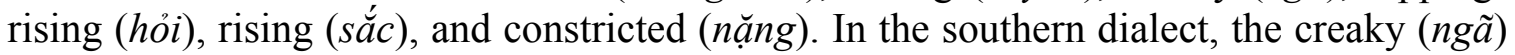
and the dipping-rising (hỏi) tones are both produced as the dipping-rising tone (höi). Therefore, there are only five tones produced in the southern regions.

\section{Consonants}

Table 1 compares Vietnamese and English consonant sounds that occur at the beginning (syllable-initial) and end (syllable-final) of words or syllables. Speech sounds are represented using International Phonetic Alphabet (IPA) symbols. Orthographic letters that correspond to how speech sounds are written are underlined in the word examples in parentheses. Consonant sounds from both northern and southern Vietnamese dialects are listed to represent the primary dialects spoken by Vietnamese Americans. Information on Vietnamese phonemes is gathered from Dinh and Nguyen (1998) and D. H. Nguyen (2001). Information on English phonemes is gathered from Erickson (2001) and Harris (1994).

At the beginning of words (syllable-initial), Vietnamese and English share the following consonant sounds: /p, b, d, k, m, n, f, v, s, z, h, l/, the r-flap in "utter" and " $y$ " in "yard." It should be noted that /p, k/ in Vietnamese are unaspirated (Dinh \& Nguyen, 1998) and may sound like "b" and "g" to an English speaker. In English, /p, k/ may be aspirated depending on context (Harris, 1994). At the end of words (syllable-final), Vietnamese and English share the following consonant sounds: /p, t, k, m, n/ and "ng." In Vietnamese, syllable-final /p, t, k/ are unreleased or "held in," whereas these sounds may be released in English.

Although Vietnamese and English share certain sounds, there are multiple consonant sounds specific to each language. In the initial position, Vietnamese-specific consonants include the dental " $\mathrm{t}$ " as in to "big" (much like a Spanish " $\mathrm{t}$ ") and the dental aspirated "t" as in tho "rabbit," which is similar to the English " $\mathrm{t}$ " but produced between the teeth. The Vietnamese "g" in gà "chicken" and the "kh" in không "no" are produced with continuous air flow (fricatives) much like a Spanish "g" in lago "lake" and "j" in jaula "cage." Other fricatives include the " $\mathrm{r}$ " in rắn "snake" (in southern dialects and certain northern dialects), and its voiceless counterpart "s" as in sáng "morning" (in the southern dialect), which is similar to the English "sh" (see table 1 for precise IPA symbols). 
Table 1

Comparison of Vietnamese and English Consonant Sounds in Syllable-Initial and-Final

Position

\begin{tabular}{|c|c|c|c|}
\hline & Vietnamese Only & Shared Sounds & English Only \\
\hline $\begin{array}{l}\text { Syllable- } \\
\text { Initial }\end{array}$ & 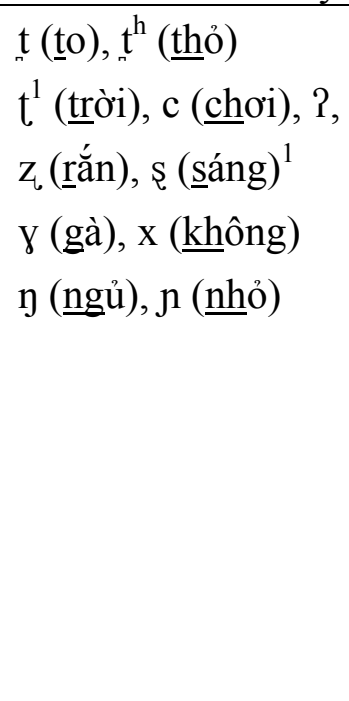 & 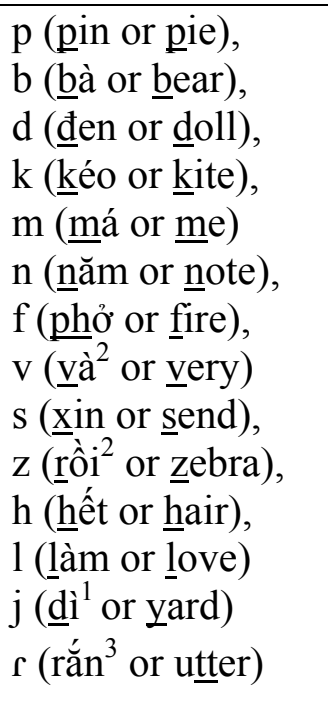 & 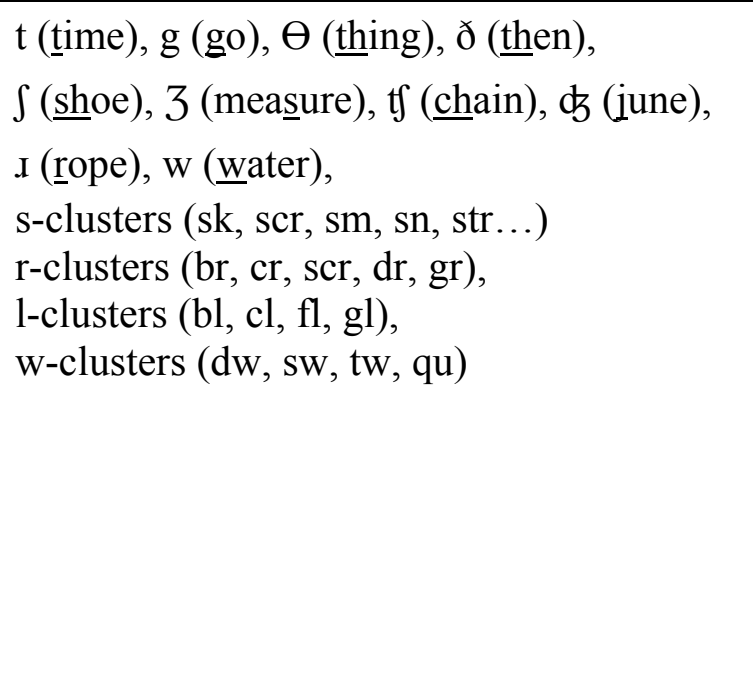 \\
\hline $\begin{array}{l}\text { Syllable- } \\
\text { Final }\end{array}$ & & $\begin{array}{l}\text { p (lớp or hop) } \\
\text { t (ít or bat), } \\
\text { k (gác or luck), } \\
\text { m (làm or lamb), } \\
\text { n (sơn or suñ), } \\
\text { y (sông or song) }\end{array}$ & 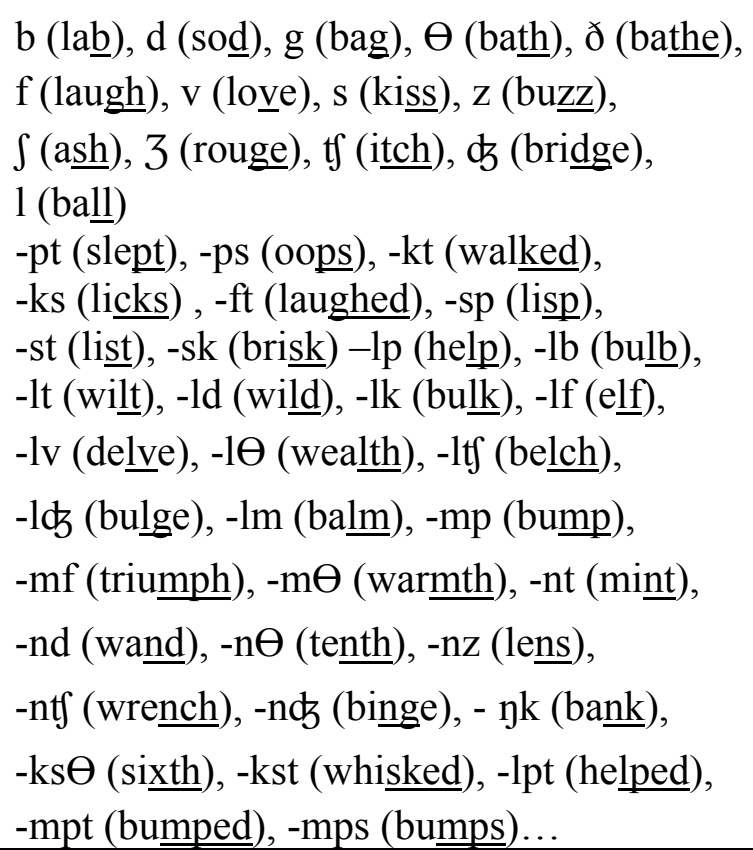 \\
\hline
\end{tabular}

Note: Consonant sounds from both northern and southern dialects of Vietnamese are based on Dinh and Nguyen (1998) and D. H. Nguyen (2001). General American English consonant sounds are based on Erickson (2001) and Harris (1994). Sounds are represented by IPA symbols. Letters that correspond to the sounds are underlined in the example words in parentheses.

${ }^{1}$ Found mainly in southern Vietnamese dialects.

${ }^{2}$ Found mainly in northern Vietnamese dialects.

${ }^{3}$ Allophone of the Vietnamese " $r$ " in southern dialects and certain northern dialects.

Vietnamese has many consonant sounds that are produced with the tongue tip curved upward and towards the back of the mouth (retroflex) such as the "tr" in trơ $i$ "sky," and "ch" in choi "to play" (similar to the English "ch"). In addition, Vietnamese has a glottal 
stop before words that are written with an initial vowel as in $\breve{a}$ "to eat" (Cao, 2004). There are certain Vietnamese sounds that are found in English but not found in the initial position such as the "ng" in ngu "to sleep" found in final position of English words such as "song" as well as the Vietnamese "nh" in nho "small" found in the middle of English words such as the "ny" in "Kenya" ( similar to a Spanish ñ). It should be noted that some Vietnamese-specific consonants are produced with the tongue tip retroflexed (3 of 11) as in trò $i$ "sky" or produced in the back of the mouth or velar position (4 of 11) as in gà "chicken"- two articulatory places that are considered relatively complex (or "marked," following Jakobson, 1968).

English also has consonant sounds not found in Vietnamese. In the initial position, English-specific sounds include /w/ in "water," /t/ in "toy" (generally aspirated; Harris, 1994), /g/ in "girl," "ch" in "chair," "dg" in "judge," "sh" in "shoe" and its rare voiced counterpart in "measure." Possibly the most well known consonant sounds specifc to English which are very difficult for second language learners include the English "r," "soft th" as in "thing," and "hard th" as in "this." In addition to single consonants, English has numerous consonant clusters (two or more consonant combinations) that involve /s, r, 1, w/ (Harris, 1994; see Table 1). Since Vietnamese only has six consonant sounds at the end of words (syllable-final), there are numerous sounds specific to English in the syllable-final position including /b, d, g, f, v, s, z, 1/, "soft th," "hard th" "sh," its voiced counterpart in "measure", "ch" "dg" in "judge," and consonant clusters that involve / $\mathrm{p}, \mathrm{f}, \mathrm{t}, \mathrm{d}, \mathrm{k}, \mathrm{l}, \mathrm{m}, \mathrm{n} /$. English appears to have a wider variety of more complex consonant sounds and sound sequences across syllable positions (see Table 1 for examples).

\section{Vowels}

Table 2 compares the vowel systems of Vietnamese (Dinh \& Nguyen, 1998; D. H. Nguyen 2001) and English (Erickson, 2001; Harris, 1994). As with table 1, orthographic letters that correspond to speech sounds are underlined in the words in parentheses. Vietnamese and English share seven single vowels: /i/ as in "see," /æ/ as in "had,"/ع/ as in "egg," / / / as in "caught," /a/ as in "cot," / / / similar to "could" and /u/ as in "blue." Apart from these shared sounds, Vietnamese contains five additional single vowels, /e/ as in le "pear," /w/ as in tu "private," / $/ \gamma /$ as in $m o$ "dream," / $\breve{\gamma} /$ as in $\hat{a} m$ "warm" and /a/ as in năm "year"; and three true diphthongs (Dinh \& Nguyen, 1998): /ie/ as in biển "sea," /uo/ as in cuốn "roll" and /ur/ as in uoót "wet." In addition, there are 20 possible twovowel combinations in which the principal vowel is combined with either a medial vowel /-u-/, or a syllable-final semi-vowel "-y" or "-w" and seven 3-vowel combinations that include all three vowel slots: medial, principal, and final (Dinh \& Nguyen, 1998; see Table 2 for examples). These two- and three-vowel combinations are commonly taught in spelling classes in the primary grades in Vietnam (e.g., Đánh vần mau, n. d.) It should be noted that these two- and three-vowel combinations maintain the overall syllable structure (Dinh \& Nguyen, 1998) and are produced in one "beat." The vowel sounds specific to Standard American English include three single vowels: /I/ in "kid," $/ \Lambda /$ in “cut," and unstressed /ə/ in “attack.” In addition, English has two rhotacized (r-rounding) 
Table 2

Comparison of Vietnamese and English vowels

\begin{tabular}{|c|c|c|c|}
\hline & Vietnamese only & Shared sounds & English only \\
\hline Singletons & 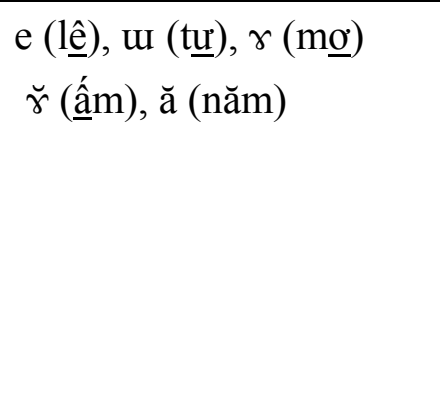 & 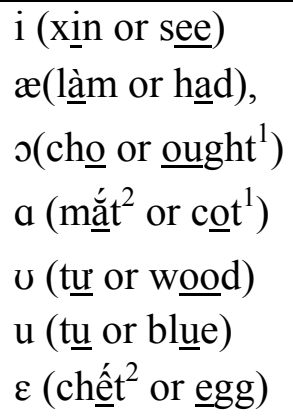 & 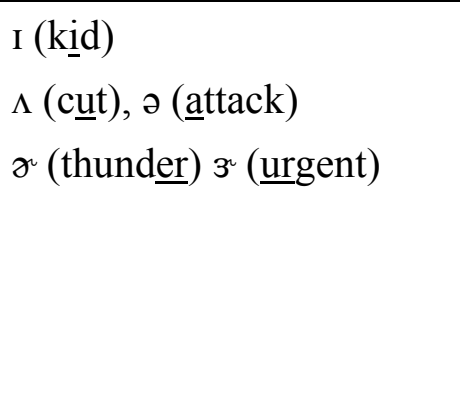 \\
\hline Diphthongs & 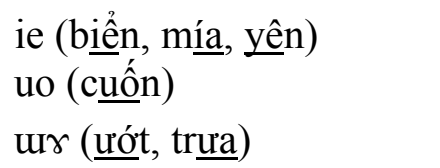 & & 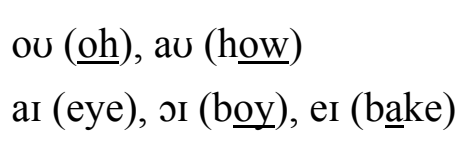 \\
\hline $\begin{array}{l}\text { 2-Vowel Combinations } \\
\text { (medial vowel -u- and } \\
\text { principal vowel) }\end{array}$ & 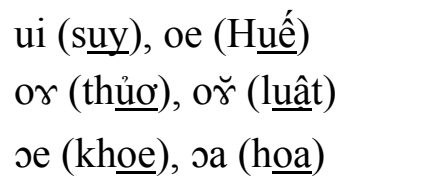 & & \\
\hline $\begin{array}{l}\text { 2-Vowel Combinations } \\
\text { (principal vowel with } \\
\text { final semi-vowel) }\end{array}$ & 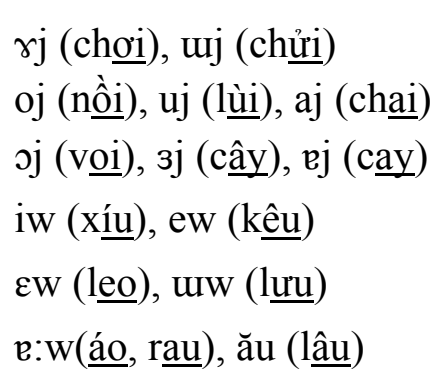 & & \\
\hline $\begin{array}{l}3+\text { vowel combinations } \\
\text { (medial vowel -u- and } \\
\text { principal vowel and } \\
\text { final semi-vowel) }\end{array}$ & 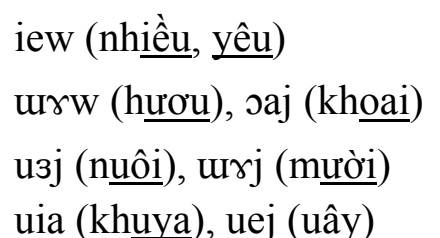 & & $\begin{array}{l}\text { aıæ (Diana) } \\
\text { ieI, (pronounciation) } \\
\text { iou (stereo }) \text {, over (ㅁasis) }\end{array}$ \\
\hline
\end{tabular}

Note: Numerous vowel differences exist among regional Vietnamese dialects (see Dinh and Nguyen, 1998, for details). This table presents Vietnamese vowels primarily from the northern dialect (Dinh \& Nguyen, 1998; D. H. Nguyen, 2001). General American English vowel sounds are based on Erickson (2001) and Harris (1994). Sounds are represented by IPA symbols. Letters that correspond to the sounds are underlined in the example words in parentheses.

${ }^{1}$ Regional dialects of American English may not exhibit a difference between /o/ and /a/.

${ }^{2}$ The phoneme /a/ may serve as an allophonic variation of /ă/ in certain Vietnamese dialects. The phoneme $/ \varepsilon /$ may serve as an allophonic variation of/e/ in certain Vietnamese dialects.

vowels $/ 3^{2} /$ in "bird" and its unstressed counterpart $/ \gamma /$ in "thunder." There are five English-specific diphthongs: /ou/ as in "oh," /av/ as in "cow," /ai/ as in "eye," /oI/ as in 
"boy," and /er/ as in "bake"; as well as four vowel combinations: /aræ/ as in "Diana," /ieI/ as in "pronunciation," /iou/ as in "stereo," and /oveI/ as in "oasis" (Harris, 1994).

\section{Syllable Structure}

Given information about the phonemes or speech-sounds of each language, it is also important to understand how these sounds combine together to form a syllable. Syllable structures in Indo-European languages may be described as sequences of consonants (C) and vowels (V). For instance, in English, there are numerous syllable structures that are plausible such as CV, CVC, CCVC, CCCVC, (Erickson, 2001) as in the words "me," "bat," "stop," and "scratch," respectively. In contrast, linguists in Vietnam have posited that representing the Vietnamese syllable using consonant and vowel sequences inaccurately portrays its structure since CV sequences would not account for tones, a compulsory element that contributes to lexical meaning, nor the adjustments in vowel length that contribute to the preservation of the syllable structure and length (H. T. Nguyen, personal communication, November 15, 2005).

Table 3 displays the syllable structure of Vietnamese (Doan, 1999; see also Dinh \& Nguyen, 1998). Double lines delineate the three main syllable components: tone, syllable-initial sound, and the rime. Tone is present throughout the syllable and carries lexical meaning (see the lexical-semantic section for a discussion of tone as a lexical unit). The onset or syllable-initial position consists solely of consonant sounds. (According to Cao, 2004, written Vietnamese words that begin with a vowel actually are produced with an initial glottal stop). The rime consists of a medial vowel, principal vowel, and final sound, of which the principal vowel is the only required vowel in the syllable (Dinh \& Nguyen, 1998). Table 3 displays four word examples that illustrate possible syllable structures: toán "math," toà "court," tan "to melt" and ta "we" or "I." Note that the smallest possible syllable, $t a$, is produced with an initial consonant sound, principal vowel, and a tone (level tones are not marked orthographically).

Table 3

Vietnamese Syllable Structure

\begin{tabular}{|c|c|c|c|}
\hline \multicolumn{4}{|l|}{ Tone } \\
\hline \hline $\begin{array}{c}\text { Syllable- } \\
\text { initial } \\
\text { sound }\end{array}$ & \multicolumn{4}{|c|}{$\begin{array}{c}\text { Redime } \\
/ \mathrm{u} /\end{array}$} & $\begin{array}{c}\text { Principal } \\
\text { vowel }\end{array}$ & $\begin{array}{c}\text { Final } \\
\text { sound }\end{array}$ \\
\hline $\mathrm{T}$ & $\mathrm{o}$ & á & $\mathrm{n}$ \\
$\mathrm{T}$ & $\mathrm{o}$ & à \\
$\mathrm{T}$ & & $\mathrm{a}$ & $\mathrm{n}$ \\
$\mathrm{T}$ & & $\mathrm{a}$ & \\
\end{tabular}


Compared to English, Vietnamese has a wider variety of single vowel and vowel combinations with a total of five unshared singletons and 30 vowel combinations compared to five unshared singletons and eight vowel combinations in Standard American English (see Table 2). A complex vowel system may be related to the Vietnamese syllable structure that allows three possible slots for vowel sounds and only two possible slots for consonants (see syllable structure in Table 3). Correspondingly, the relatively limited number of consonants may be related to their limited role in a syllable. A relatively larger vowel inventory may counterbalance a more limited number of consonants in Vietnamese.

Based on this comparison of Vietnamese and English phonology, we find that while certain speech sounds are common to both languages, there are many differences to be noted. First, tones in Vietnamese carry lexical meaning and are obligatory in the syllable structure. Second, Vietnamese has a more complicated vowel system, while English has a larger consonant inventory with greater distribution across syllable positions. Lastly, in regards to complexity, Vietnamese contains multiple relatively marked retroflex and velar consonant sounds, while English contains complex structures such as affricates and consonant clusters.

\section{Lexical Semantics}

\section{Lexical Tone}

Moving from a comparison of the sound structure, we now compare Vietnamese and English at the word level. A critical element of the Vietnamese word is lexical tone. Traditionally, tones of tonal languages have been described as phonemes (see phonological section above for details). However, tones may also be viewed as contributing to the lexical-semantic meaning of words. D. H. Nguyen (1997) describes how specific patterns of tone change are used as a lexical unit. One example is the use of the dipping-rising ( $h o b i)$ tone with pronouns to indicate third person reference in the southern (Sài Gòn) dialect (see discussion below on kinship terms used as pronouns). For example, in the northern dialect a pronoun is followed by the word $\hat{a} y$ to refer to the third person such as anh, the pronoun that indicates a man who is slightly older than the speaker, as in anh ấy "he" or "that man." The southern dialect allows for the use of the dipping-rising (hỏi) tone to indicate third person reference in spoken language (D. H. Nguyen, 1997). For example, instead of anh ấy "he" or "that man," the level (không dấu) tone is replaced by the dipping-rising ( $h o b i)$ tone to indicate third person reference, anh "he." This tone substitution is also found in select words such as trong "in," changed to trỏng "in there" and bên "side," changed to bển "that side" (D. H. Nguyen, 1997). Unlike Vietnamese, English is not a tonal language, thus tones are not used as lexical items. Instead of a tone substitution, English would indicate this change in meaning with the addition of another word such as "this" and "that."

\section{Lexical Function}

Both English and Vietnamese words can be divided into content words and function words. Content words carry lexical meaning, while function words relate lexical words to 
each other (Stubbs, 2001). For both languages, content words may be further divided into nouns, verbs, and adjectives. Nouns are words that represent entities; verbs represent actions or states, and adjectives represent qualities or characteristics (Kreidler, 1998).

In Vietnamese as well as in English, words have the capability to change word class, and thus change in meaning. Kreidler (1998) described the semantic meaning underlying changes in word class. For instance, when verbs become nouns, an action becomes a countable entity (e.g., "to kick" and "a couple of kicks"). When a noun becomes a verb, it describes the process or completion of an action (e.g., "a mine" and "mining"). The following examples of changes in word class are from K. L. Nguyen (2004) for Vietnamese and Kreidler (1998) for English. Nouns can become verbs such as "a box" and "to box" in English and môt bó "[one] bundle" and bó "to bundle" in Vietnamese; and verbs can become nouns such as "to kick" and "a kick" in English and cura "to saw" and cái cua "a saw" in Vietnamese. Adjectives can become nouns such as "warm" to "warmth" in English and khó khăn "difficult" and một cái khó khăn "a struggle" in Vietnamese; Nouns can become adjectives such as "child" to "childish" in English and cái lý tương "an ideal" to [rất] lý tương "[quite] ideal" in Vietnamese. In addition, certain Vietnamese nouns can be used as pronouns. For example, bác sĩ "doctor" may be used as a second person reference pronoun in the sentence Bác sĩ nghi thế nào? [Doctor think what] "What do you think?" Kreidler (1998) did not report this conversion between nouns and pronouns in English. However, in English, adjectives can become verbs such as "to bore" and "boring." K. L. Nguyen (2004) did not report Vietnamese adjectives becoming verbs, perhaps because many linguists (e.g., D. H. Nguyen, 1996) argue that Vietnamese adjectives should be classified as stative verbs.

In English, words may keep the same form (e.g., "to kick" and "a kick") or have a different form to indicate a change in word class (e.g., "child" and "childish"), whereas Vietnamese words never change in form to indicate a change in word class. For both languages, when there is no change in form, a change in word class is indicated in context of surrounding words. For example, in English, the article "a" signals a noun as in "a kiss," while the word "to" indicates a verb as in "to kiss" (Nelson, 1995). Similarly in Vietnamese, a numeral, quantifier, or classifier signals a noun as in môt bó "a bundle," nhĩng bó "some bundles" and cái bó "[classifier] bundle," respectively, while modifiers indicate a verb as in đã bó rồ [completed-aspect-marker to-bundle already] "to have bundled already" (K. L. Nguyen, 2004).

\section{Classifiers}

In addition to word classes of nouns, verbs, and adjectives, Vietnamese has another group of words not found in English-classifiers. There is much controversy as to whether classifiers are a distinct word class (Aikhenvald, 2000) or whether they are a subclass of nouns (Alves, 1999; Cao, 1998) that have a classifying function. Although this debate is beyond the scope of this paper, it is noted that the term "classifier" is used here to describe this group of words and is not intended to favor either viewpoint.

Classifiers are used to categorize objects by a single attribute such as shape or animacy, and may reflect how different cultures perceive or "divide up" the world around them (Aikhenvald, 2000). In many Southeast Asian languages, the prototypical noun phrase that requires a classifier is [Numeral + Classifier + Noun] (Adams, 1989) such as 
hai con chó [two cl-animacy dog] "two dogs." The exact number of Vietnamese classifiers varies from over 200 (D. H. Nguyen, 1957) to 4 (Cao, 1998). (For detailed information on the debate on classifiers, see Cao, 1988 as well as Loại tù trong các ngôn

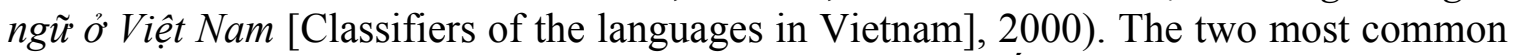
classifiers in Vietnamese indicate animacy (con as in con gấu "bear") and inanimacy (cái as in cái ghế "chair"). There are Vietnamese words that classify the shape and size of objects such as cây (long and slender) in cây vàng "long piece of gold," cuốn (long and cylindrical) in cuốn phim "camera film," and mảnh (small piece) in mảnh vải "small piece of [torn] cloth." There are also words that indicate a set or group of objects such as bộ, nhóm, đàn in bộ chén "set of dishes," nhóm ngươ "group of people," and đàn bò "herd of cows" or đàn vịt "flock of geese" (K. L. Nguyen, 2004).

English speakers may have difficulty understanding the role and function of classifiers since English does not have an equivalent word type. Although quite limited in scope, comparisons have been made between classifiers and English words such as "sheet" in the phrase "one sheet of paper." This type of word in English seems infrequent and may ultimately be incomparable to Vietnamese classifiers in frequency and use (Aikhenvald, 2000; Daley, 1998).

\section{Pronouns}

Another element related to lexical semantics is how Vietnamese and English speakers use words to make reference to persons or items in the world around them. In most languages, there are words of which their referent can only be determined in context such as "this," "she," and "you" (Kreidler, 1998). An example of this type of word is the pronoun.

Both Vietnamese and English have pronouns to substitute for nouns or noun phrases. Although there are a few pronouns in Vietnamese that can be used in a general sense such as tô $i$ "I," most Vietnamese pronouns are kinship terms, and their use depends on the social context and the relationship between the speaker and listener (Luong, 1990). Vietnamese kinship terms are used to address family and non-family members. Within the family, there are kinship terms to distinguish between sides of the family, such as $n \hat{o} i$ "paternal" and ngoai "maternal." Kinship terms also indicate age, gender, and blood relations versus in-law status. Examples of kinship terms that indicate age and gender include chị "older sister," anh "older brother," em "younger sibling," bác "father or mother's older sibling" (in the northern dialect), $d i$ "aunt or mother's younger sister," cô "aunt or father's younger sister," chú "uncle or father's younger brother" and cậu "uncle or mother's younger brother" (Luong, 1990). Kinship terms that distinguish between blood relations and in-law status include thim "aunt or wife of father's younger brother," and $m o$ " "aunt or wife of mother's younger brother." In addition, kinship terms vary among regional dialects. For instance the kinship term for "uncle or mother's younger sister's husband" is chú in the northern dialect and duơng in the southern dialect $(\mathrm{K}$. L. Nguyen, 2004).

In Vietnamese, the speaker and listener address each other and themselves differently depending on the social context. Even though the listener is not a family member or relative, kinship terms are used as pronouns to address and refer to friends and unfamiliar interlocutors (Luong, 1990). For example, a person who is approximately the 
age of one's uncle or aunt could be addressed as chú or cô, respectively. In addition, the way in which one addresses himself or herself depends on the listener's age and status. For instance, when meeting someone approximately the age of one's aunt or uncle, it is common to address oneself as cháu "niece/nephew" in the northern dialect or con "son/daughter" in southern dialect. When meeting someone approximately the age of one's older sister, one may address himself or herself as em "younger sibling" and address the speaker as chi "older sister." It is common to address the listener with pronouns that indicate an older age as a sign of respect (Luong, 1990); typically, the older the age, the higher the status. English pronouns are not dependent on the social or personal relationship between the speaker and listener, nor do they indicate age or status.

As summarized by Erickson (2001), English uses distinct pronouns to indicate first person (e.g., I, me), second person (e.g., you), and third person (e.g., she, he, it). English marks gender in the singular third person (e.g., she, he) and number in the first person (e.g., "I" vs. "we") and third person (e.g., "she" vs. "they"). In addition, there are different pronouns that indicate subject vs. predicate position (e.g., "she" vs. "her"). In contrast, Vietnamese pronouns remain the same and do not indicate number, subject or predicate position, nor first, second, and third person. In order to indicate plurality in Vietnamese, a quantifier is added before the pronoun. For example, các "some" is added before chu' "uncle" to indicate more than one male who is approximately the age of one's uncle: các chú.

\section{Word Formation}

We now turn to a comparison of how Vietnamese and English form new words. English words are polysyllabic, with most words containing one to five syllables (Erickson, 2001). In earlier studies (e.g., Thompson, 1965), Vietnamese has been inaccurately reported to be a monosyllabic language with each word equal to one syllable. Currently, linguists agree that Vietnamese words may consist of one, two, three, or even four syllables; D. H. Nguyen (1997) suggested that $80 \%$ of Vietnamese words actually consist of two syllables. English and Vietnamese have two ways of forming new words: affixation and compounding.

Affixation is the process of attaching small units (i.e., morphemes) to a word to change its meaning. In English, content words can have attached inflections such as a prefix at the beginning of a word (e.g., "un-" in "unreal") or a suffix at the end of a word (e.g., "-ful" in "wonderful"). According to D. H. Nguyen (1997), Vietnamese uses prefixes and suffixes as well, but rather than attaching them to the word itself, prefixes and suffixes appear as separate words, as in the examples below:

a. the prefix bán "half, semi" in front of cầu "sphere or ball" forms the word bán cầu "hemisphere";

b. the suffix hóa "-ize, -fy" following địa cầu forms địa cầu hóa "to globalize" or "globalization."

There are linguists who may disagree with this account and consider these examples as compounding (e.g., Do, 1981). 
Compounding is the process of combining two or more words together to create a new word (American Heritage Dictionary, 2000). Both languages combine nouns, verbs, and adjectives to create compound words. Most English compounds are composed of two nouns and have an endocentric semantic function (Bauer, 1983). For instance, "armchair" and "beehive" are endocentric because an armchair is a type of chair, and a beehive is a type of hive. Vietnamese compounds may also have an endocentric function. For instance, hải quân "[the] navy" is a type of quân "army" (hải "ocean"). In addition, Vietnamese compounds may have a generalizing function. A generalizing compound consists of two similar items that combine to indicate a larger concept. D. H. Nguyen (1997) provided examples of generalizing compounds:

a. the words bàn "table" and ghế "chair" combine to mean bàn ghế "furniture";

b. the words con "child" and cháu "grandchild" combine to mean con cháu "offspring, descendents."

In English, generalizing compounds occur less frequently than the endocentric type (Baur, 1983).

Another way a word can be compounded is through reduplication. Reduplication rarely occurs in English and is primarily used in words that reflect sounds or noises such as "click clack" (Thompson, 1965). Vietnamese frequently uses reduplication across word classes of verbs, adjectives, and nouns. They may consist of the replication of an entire syllable or of its individual components such as the rime, initial consonant sound, or principal vowel (G. T. Nguyen, 2003; see Table 3 on syllable structure). For the purposes of this discussion, only examples of reduplications involving the repetition of an entire syllable are described in order to focus on the semantic meaning rather than the syntactic form. For a detailed description of reduplications, see C. T. Nguyen (1999), D. H. Nguyen (1997), G. T. Nguyen (2003), and K. L. Nguyen (2004).

Earlier studies on Vietnamese have suggested that reduplications, as in English, primarily reflect sounds and noises (Thompson, 1965). Vietnamese reduplications have been shown to have multiple semantic functions (C. T. Nguyen, 1999; G. T. Nguyen, 2003). In general, when a verb is repeated, this reduplication indicates movement. For instance gật [đầu] "to nod [one's head]" can be reduplicated to indicate a repetitive nodding motion: gật gật đầu. In the case of adjectives, reduplication can imply a lesser degree of a quality. For example, one can imply that a girl is not as pretty as previously thought: Cô ta xinh "She is pretty" versus Cô ta xinh xinh "She is kind of (or less) pretty." Color terms such as "green," xanh, can have a lighter shade by reduplicating the word, xanh xanh. Certain nouns can be reduplicated to indicate reoccurrence or multiple instances such as ngày ngày "day day," which implies many days or all days (C. T. Nguyen, 1999; G. T. Nguyen, 2003).

In summary, there are multiple similarities and differences between Vietnamese and English at the lexical-semantic level. Table 4 compares the presence or absence of the previously discussed semantic features across languages. Both Vietnamese and English divide words into two general groups: content (or lexical) and function words. Content words are further divided into nouns, verbs, and adjectives and have the capacity to change word class such as a noun to a verb (D. H. Nguyen, 1997; Kreidler, 1998). 
Both languages have pronouns to address and refer to people, although pronouns of each language exhibit different embedded meanings. English pronouns mark for gender, number, person, and grammatical position (Erickson, 2001), while Vietnamese pronouns mark for gender and status (Luong, 1990). Both languages use affixation and compounding to form new words (Bauer, 1983; D. H. Nguyen, 1997; Kreidler, 1998; Stubbs, 2001), while Vietnamese uses reduplication (C. T. Nguyen, 1999; G. T. Nguyen, 2003), a type of compounding, far more frequently and with more semantic complexity than English.

Table 4

Comparison of select lexical-semantic features of Vietnamese and English words

\begin{tabular}{|c|c|c|}
\hline Lexical Semantic element & Vietnamese & English \\
\hline Lexical tone & $\mathrm{x}$ & \\
\hline Content and function words & $\mathrm{x}$ & $\mathrm{x}$ \\
\hline Entities (nouns), actions and states (verbs), qualities (adjectives) & $\mathrm{x}$ & $\mathrm{x}$ \\
\hline Classifiers & $\mathrm{x}$ & \\
\hline Reference marker (pronoun) & $\mathrm{x}$ & $\mathrm{x}$ \\
\hline Indicates gender & $x^{a}$ & $\mathrm{X}$ \\
\hline Indicates number & & $\mathrm{x}$ \\
\hline Indicates person & & $\mathrm{x}$ \\
\hline Indicates age/status & $\mathrm{x}$ & \\
\hline Indicates subject or predicate position & & $\mathrm{x}$ \\
\hline Affixation & $\mathrm{x}$ & $\mathrm{x}$ \\
\hline Prefixes & $\mathrm{x}$ & $\mathrm{x}$ \\
\hline Suffixes & $\mathrm{x}$ & $\mathrm{x}$ \\
\hline Compounding & $\mathrm{x}$ & $\mathrm{x}$ \\
\hline Endocentric meaning & $\mathrm{x}$ & $\mathrm{x}$ \\
\hline Reduplication & $x^{b}$ & \\
\hline
\end{tabular}

Note: Information on English gathered from Bauer (1983), Erickson (2001), Kreidler (1998), and Stubbs (2001). Information on Vietnamese gathered from Luong (1990), C. T. Nguyen (1999), D. H. Nguyen (1997), and G. T. Nguyen (2003).

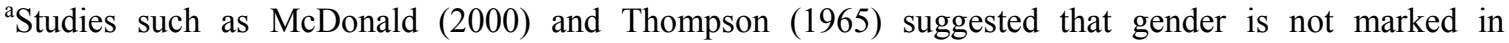
Vietnamese pronouns. I argue that although gender and age/status cannot be separated in Vietnamese pronoun use, they are both marked in most pronouns such as cô (younger female).

${ }^{b}$ Although found in English, reduplication seems to be restricted to reflect sounds and noises (D. H. Nguyen, 1997).

\section{Morpho-Syntax}

Previous subsections compared Vietnamese and English across sound and word levels. This subsection compares the morpho-syntactic or grammatical systems of the two languages at phrase and sentence levels. Vietnamese and English differ greatly in regards to grammatical structures. English is a moderately inflected language that uses morphological morphemes (smallest units of meaning) to mark tense (e.g., -ed) and number (e.g., plural -s) (see Quirk, Greenbaum, Leech, \& Svartivik, 1989, for a detailed description of English grammar). Vietnamese is an isolating language in that the grammar primarily consists of word order and the use of function words rather than 
bound morphemes (see D. H. Nguyen, 1997, D. L. Nguyen, 1970, and H. V. Nguyen, 2003 for overviews of Vietnamese grammar).

Table 5 summarizes certain grammatical characteristics of Vietnamese and English. Apart from a general word order of subject-verb-object (SVO) and primary use of active voice, the majority of grammatical characteristics are not shared between the languages. In English, adjectives precede nouns; in Vietnamese adjectives follow the nouns they describe. English content questions are formed with a question word at the beginning of the sentence with a movement of the auxiliary verb (Erickson, 2001): the declarative sentence, "She is going to the store," can be restated as a question "Is she going to the store?" in which the auxiliary verb "is" and the subject "she" have changed places. This transposition does not occur in Vietnamese, in which content questions are formed using the same SVO structure of a declarative sentence with the placement of a question word in the slot that would contain the answer (D. H. Nguyen, 1997). For instance, a WH question Cô $\hat{a} y$ đi đâu? [Miss-she go where] "Where are you going?" may be answered with $C \hat{o}$ ấy đi $\underline{c h o}$. [Miss-she go store] "She is going to the store," in which the question word, đâu "where," is replaced with the answer, cho" "store." In the Who-question $\underline{A i}$ muốn ăn? [Who want eat] "Who wants to eat?" the question word, ai "who," is replaced by the answer Tôi "I": Tôi muốn ăn [I want eat] "I want to eat." For a detailed description of question types, see D. H. Nguyen (1997) and D. L. Nguyen (1970).

In regards to negation, Vietnamese has two general forms, while English has three general forms. In Vietnamese, negation may be indicated using không "no" before the verb as in Tôi không ăn [I no eat] "I will not eat." When the copula, là, is used, the phrase không phải [no correct] must be used as in Nó không phải là mèo [It no correct to-be cat] "It is not a cat" (D. H. Nguyen, 1997). According to Erickson (2001), negation in English may be indicated using "not" in between the auxiliary verb and the verb phrase as in "She could not open the door." When the auxiliary verb is not present, the negative form of a sentence includes a form of "do" before "not": compare the affirmative sentence "Bill opened the door" and the negated sentence "Bill did not open the door." In addition, spoken English often uses the contraction $-n$ ' $t$ in place of "not" as in "She could $n$ ' $t$ open the door."

Vietnamese also differs from English in that it does not morphologically mark tense, aspect, or number. Tense is represented with words that precede the verb such as đã, đang, sẽ to indicate past, present, and future respectively. However, these tense markers are not required for a sentence to be grammatically correct and are often inferred

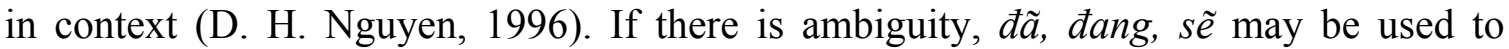
clarify the context. English uses certain verb inflections to indicate tense and aspect. Past tense is marked with the verb inflection -ed; the present progressive aspect is marked with -ing (Erickson, 2001).

The feature of number (singular vs. plural) is indicated differently in English and Vietnamese. English requires the use of the plural marker $-s$ or -es (Erickson, 2001), such

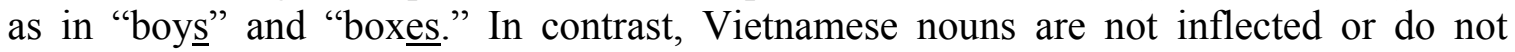
change to a plural form; number is indicated through the addition of numerals such as môt con gà for "one chicken" and hai con gà for "two chickens," and quantifiers such as 
Table 5

Comparison of Selected Vietnamese and English Grammatical Characteristics

\begin{tabular}{|c|c|c|}
\hline & Vietnamese & English \\
\hline $\begin{array}{l}\text { Word } \\
\text { order }\end{array}$ & $\begin{array}{l}\text { SVO, OSV less common } \\
\mathrm{N}+\text { Adj }\end{array}$ & $\begin{array}{l}\mathrm{SVO} \\
\mathrm{Adj}+\mathrm{N}\end{array}$ \\
\hline Voice & Primarily Active & Primarily Active \\
\hline $\begin{array}{l}\text { Content } \\
\text { questions }\end{array}$ & 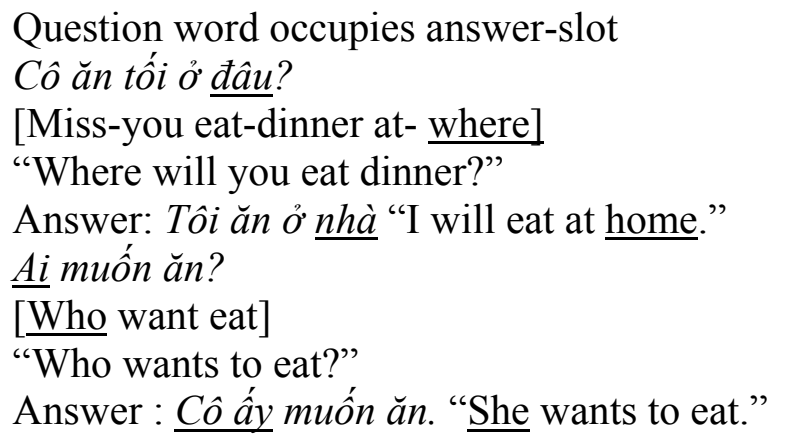 & $\begin{array}{l}\text { Question word }+ \text { auxV }+\mathrm{S}+\mathrm{V} \ldots \\
\text { Where will you eat dinner? } \\
\text { What would you like to eat? }\end{array}$ \\
\hline Negation & $\begin{array}{l}\text { 1. không + V : Tôi không ăn. } \\
\text { [I no eat] } \\
\text { "I will not eat." } \\
\text { 2. không phải + là (copula): } \\
\text { Tôi không phái là sinh viên. } \\
\text { [I no-correct to-be student] } \\
\text { "I am not a student." }\end{array}$ & $\begin{array}{l}\text { 1. S + auxV + "not" + V phrase } \\
\text { She could not open the door. } \\
\text { 2. If auxV not present: "do" + not } \\
\text { Bill opened the door. } \\
\text { Jane did not open the door. } \\
\text { 3. Contraction "-n't" } \\
\text { She couldn't open the door. }\end{array}$ \\
\hline $\begin{array}{l}\text { Tense \& } \\
\text { Aspect }\end{array}$ & 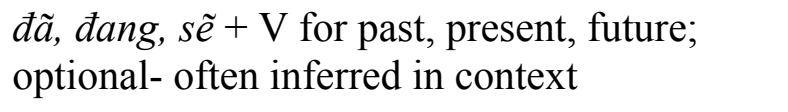 & -ed, - ing, will $+\mathrm{V}$ \\
\hline Number & $\begin{array}{l}\mathrm{N}: \text { numbers/quantifiers }+\mathrm{N} \\
\mathrm{V}: \text { do not indicate number }\end{array}$ & $\begin{array}{l}\mathrm{N} \text { : Plural }-\mathrm{s},-\mathrm{es} \\
\mathrm{V} \text { : Present } 3^{\text {rd }} \text { person singular }-\mathrm{s}\end{array}$ \\
\hline Possession & $\begin{array}{l}\text { của }+\mathrm{N} \quad \text { or cúa omitted } \\
\text { nón của me } \\
\text { nón mẹ of mom] } \\
\text { "Mom's hat" }\end{array}$ & $\begin{array}{l}\text { Possessive marker: N's as in Bob's } \\
\text { Phrase: of + N as in “of Bob" } \\
\text { Possessive pronouns: hers, his, ours }\end{array}$ \\
\hline Compare & $\begin{array}{l}\text { Adj, Adj + hơn, Adj + nhất } \\
\text { cao "tall," cao ho"n "taller," cao nhất "tallest" }\end{array}$ & $\begin{array}{l}\text { Adj, Adj+ -er, Adj+- est } \\
\text { tall, taller, tallest } \\
\text { More + Adj "more basic" } \\
\text { Irregularities "good, better, best" }\end{array}$ \\
\hline Classifiers & $\begin{array}{l}\text { Numeral + Classifier + Noun } \\
\text { hai con chó } \\
\text { [two cl-animacy dog] } \\
\text { "two dogs" }\end{array}$ & Does not have classifiers \\
\hline
\end{tabular}

Note: $\mathrm{N}$ = noun; Adj = Adjective; $\mathrm{V}=$ Verb; $\mathrm{S}=$ Subject; $\mathrm{O}=$ Object; Aux = auxilary. Information on Vietnamese grammar gathered from D. L. Nguyen (1970), D. H. Nguyen (1997), and H. V. Nguyen (2003). Information on English grammar gathered from D. L. Nguyen (1970) and Erickson (2001). 
nhĩng con gà for "some chickens." Both Vietnamese and English have a rule for marking possession with the word "of" between the possessed object and the possessor, such as cái nón của con gái "the hat of the girl." In Vietnamese, there is the option of including của "of" or omitting it such as xe ban for "car [of a] friend." English has additional ways to mark possession. It commonly uses the morpheme -'s attached to nouns such as "a girl's hat" or possessive pronouns "It's hers" (Erickson, 2001). The feature of comparatives are marked with additional words in Vietnamese (i.e., ho"n "more" and nhất "most") compared with English noun inflections "-er, est," with some exceptions to the rule (see Table 5 for examples). As mentioned in the lexical semantic subsection, Vietnamese American children may have difficulty with classifiers in Vietnamese since they are not present in English. An omission of a classifier may indicate a change in word meaning (semantics, see previous subsection) as well as a change in grammar (morphosyntax). For instance an omission of a required classifier would make a noun phrase (Numeral + Classifier + Noun) ungrammatical such as if the noun phrase hai con chó "two dogs" were incorrectly produced as hai chó*.

This completes section two of this paper on a cross-linguistic comparison of Vietnamese and English across the sound, word, and sentence levels. Section 3 focuses on predictions of cross-linguistic interactions within a speaker. These potential interactions are described across the language levels of phonology, lexical semantics, and morpho-syntax.

\section{Potential Vietnamese-English Interactions}

Based on the cross-linguistic comparison of Vietnamese (L1) and English (L2) in Section 2 , it is possible to predict and describe how these languages may interact. Within the Vietnamese American population, there are at least two distinct speaker groups: the Vietnamese adult L2 learner and the Vietnamese American child learning both languages either simultaneously or sequentially (i.e., L1 at home with exposure to L2 shortly after). These two speaker groups are often found within individual family structures. For example, the parents in a family may belong to the first speaker group (the adult L2 learners), while the children may belong to the second speaker group. Other speaker groups may include Vietnamese adolescents and children who have newly arrived to the United States. Newly arrived Vietnamese adolescents may demonstrate similar characteristics to the adult speaker group, while newly arrived young children may experience shifts in relative language dominance. For the sake of simplicity, this paper separates speakers into two general groups of adults and children. However, the example of a new arrival group underscores the importance of assessing all speakers on an individual basis, recognizing factors particular to each speaker such as previous language experiences.

This section presents predictions about potential language interactions between Vietnamese and English within individual speakers. Since little to no research has been conducted on L1-L2 interactions in Vietnamese Americans, it may be helpful to analyze the language characteristics of these two general groups to better understand how Vietnamese may influence English (particularly in the adult speaker group) and how English may influence Vietnamese (in the child speaker group). 
This section is divided into two parts. The first part describes language characteristics of Vietnamese L2 learners of English who most likely are adolescents or adults. This speaker group may include Vietnamese parents as well as newly-arrived Vietnamese students in their teenage years. The influence of Vietnamese (L1) skills on English (L2) performance is described. Information is based on previous studies of L2 acquisition (e.g., McDonald, 2000; Riney, 1988; Sato, 1988) and anecdotal evidence from Vietnamese adult informants. Further investigation is needed to verify and expand on the description of linguistic features of this population. The second part of this section describes language characteristics that may occur in Vietnamese American children acquiring both languages, either simultaneously or sequentially. Although not specifically on Vietnamese-English speakers, the literature on sequential bilingualism of minority languages in the United States suggests that children tend to shift in relative strength from L1 to L2 (Anderson, 2004). Oftentimes L2 becomes the relatively dominant language with a higher rate of development than L1 (Kan \& Kohnert, 2005; Kohnert, 2002; Kohnert \& Bates, 2002; Kohnert, Bates, \& Hernandez, 1999). English (L2) may be attained with native-like proficiency, and the child's L1 performance may be influenced by their relatively dominant L2 (Hernandez, Bates, \& Avila, 1994; Su, 2001). Virtually no research studies have been conducted on the language acquisition of VietnameseEnglish bilingual children or Vietnamese monolingual children (though see Tang \& Barlow, 2006). Therefore the following predictions are based on the cross-linguistic comparison described in Section 2, anecdotal evidence based on the author's familiarity with both languages, and consultation with Vietnamese language teachers. Empirical evidence on the language skills of Vietnamese American children is necessary to support or refute these predictions and to increase our overall understanding of how children learn two languages.

\section{Vietnamese Transfer to English}

Adult L2 learners often transfer L1 skills onto their L2 (McDonald, 2000). Transfer from L1 to L2 is often referred to as positive transfer. The following description is meant to highlight salient linguistic features specific to English with which Vietnamese speakers may have difficulty. Obviously not all Vietnamese adult L2 learners will demonstrate all characteristics of Vietnamese-influenced English. Factors such as age of arrival, age of English acquisition, years of formal instruction, language and dialect of the surrounding community, and opportunities to practice with native English speakers play a large role in the degree of transfer of L1 skills to L2 performance (e.g., Flege, Yeni-Komshian, \& Liu, 1999; Genesee, Paradis, \& Crago, 2004; McDonald, 2000).

Table 6 summarizes examples of potential interactions from Vietnamese to English across phonology, lexical semantics, and morpho-syntax. In regards to phonology, Vietnamese adult L2 learners often have difficulty pronouncing English sounds not found in Vietnamese such as consonant clusters, affricates, vowels with rrounding $/ \gamma^{c}, 3^{\circ} /$, and lax vowel $/ \mathrm{I} /$ (see Tables 1 and 2). Consonant clusters may be simplified or deleted depending on the word position (D. L. Nguyen, 1970b; Riney, 1988). For instance, the initial consonant cluster /str-/ in "string" may be simplified and produced without the /t/ as "sring" [srin], with a tense high vowel [i] instead of the lax 
vowel /I/, which is not present in Vietnamese. A consonant cluster in the word-final position as in "walked" may be deleted and produced as "walk."

In addition to omitting sounds, L2 learners may substitute English-specific sounds with Vietnamese sounds or sounds shared between both languages (McDonald, 2000; Riney, 1988). For instance the English "hard th" in "the" may be approximated with [d], a shared sound, as in [də]. In the final position, a "hard th" may be produced as the shared sound /t/ as in [smut?] for /smuð/ "smooth." The English "soft th" may be approximated

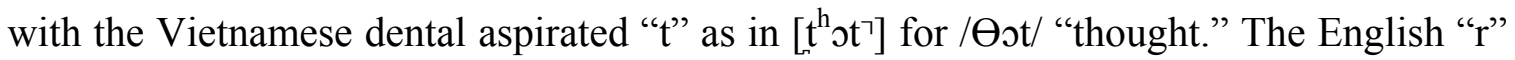
in "run" may be produced as the r-flap (an acceptable allophone for the Vietnamese " $r$ ") or as /z/ (from the northern Vietnamese dialect): "run" or "zun." English final "r" may be omitted as in [sta] for "star." English final /1/ may be produced with the semivowel [w] such as [snew] for /snerl/ "snail" (D. L. Nguyen, 1970b). Since tones are obligatory in every Vietnamese word, Vietnamese speakers may add tones into English, which would affect intonation patterns.

Table 6

Potential Interactions of Vietnamese (L1) with English (L2)

\begin{tabular}{|c|c|c|}
\hline Lang. level & Pattern & Example \\
\hline \multirow{5}{*}{$\begin{array}{l}\text { Phonology } \\
\text { (Sound } \\
\text { level) }\end{array}$} & Simplify initial consonant clusters & sring for "string" \\
\hline & Delete or simplify final consonant clusters & bok for "box" \\
\hline & Substitute with Vietnamese consonants & $\begin{array}{l}\text { Dental aspirated " } t \text { " for "soft th": } \\
{\left[\mathrm{t}^{\mathrm{h}} \mathrm{ot}{ }^{\mathrm{T}}\right] \text { for "thought" }}\end{array}$ \\
\hline & Substitute with Vietnamese vowels & cheek for "chick" \\
\hline & Intonation pattern influenced by tones & $\begin{array}{l}\text { Rising and falling on individual } \\
\text { words }\end{array}$ \\
\hline $\begin{array}{l}\text { Lexical- } \\
\text { Semantic } \\
\text { (Word } \\
\text { level) }\end{array}$ & $\begin{array}{l}\text { Difficulty using words that do not have } \\
\text { direct Vietnamese translations } \\
\text { Difficulty with endings that indicate a } \\
\text { change in word class }\end{array}$ & $\begin{array}{l}\text { "To do," "to work," and "to make" } \\
\text { are all one word in Vietnamese, làm } \\
\text { so bore for "so boring" }\end{array}$ \\
\hline \multirow{6}{*}{$\begin{array}{l}\text { Syntax } \\
\text { (Grammar) }\end{array}$} & Omit word endings for tense & walk for "walked" \\
\hline & Omit word endings for plurality & two dollar for "two dollars" \\
\hline & Omit word endings for verb agreement & she walk for "she walks" \\
\hline & Omit auxiliary verbs & You hungry? for "Are you hungry?" \\
\hline & Place adjectives after nouns & car big for "big car" \\
\hline & Difficulty with word order in questions & $\begin{array}{l}\text { You want eat what? for "What do } \\
\text { you want to eat?" }\end{array}$ \\
\hline
\end{tabular}

Note: This table displays potential influences of Vietnamese (L1) on English (L2). These patterns more likely occur in adolescent or adult learners of English as a second language. Individual speakers would not necessarily exhibit all of these patterns depending on their age at exposure to English, manner in which English was learned, individual learning style, etc. 
A potential interaction at the word level may be related to multiple-to-one word mappings, namely, when one language has multiple words that equate to only one word in the other language. Based on my own familiarity of Vietnamese and English, the following are a couple of anecdotal examples: the English verbs "to do," "to work" and "to make" are all expressed as one Vietnamese verb, làm; English words that describe groups of animals such as "herd [of cattle]," "flock [of geese]" and "school [of fish]" are all expressed using the plural classifier, đàn. It may be difficult for Vietnamese speakers to use English vocabulary that consists of lexical-semantic distinctions not present in Vietnamese.

Another potential interaction that involves both meaning and grammar is related to word class conversion. As mentioned earlier, both English and Vietnamese words have the capability of changing word class such as from a noun to a verb (see the lexicalsemantic subsection for details). In English, a change in word class oftentimes involves a change in form (e.g., "child" to "childish"). In Vietnamese, word forms do not change, but rather a noun becomes a verb based on the context of the sentence. From a grammatical viewpoint, Vietnamese adult speakers may change the word class of English words without changing the word form (e.g., "The book is so bore" for "The book is so boring.") From a lexical-semantic viewpoint, Vietnamese adult speakers may rely on sentential context (rather than morpho-syntactic markers) to use or interpret, in this example, a noun as an adjective.

At the grammatical level, Vietnamese speakers may have difficulty with English noun and verb inflections since their L1 does not use morphological markers such as the past tense verb marker $-e d$, plural $-s$, and third person singular $-s$ (McDonald, 2000). For instance, Vietnamese speakers may use the present tense verb to indicate tenses of past or future. The omission of certain morphological markers may also be related to phonology since the final /s/ and consonant clusters (e.g., "walked" /wokt/) are specific to English.

Another potential interaction may be with differences in word order. For instance, nouns come before adjectives in Vietnamese, while adjectives come before nouns in English. Word order of content questions in English may also be influenced by Vietnamese. Dominant Vietnamese speakers may have difficulty with inverting subjectverb word order or even including auxiliary verbs when asking questions in English (McDonald, 2000). The auxiliary verb may be omitted altogether, and the question word may be placed in sentence-final position to fill the answer slot (see Table 5) such as "You go where?" for "Where are you going?" or "You drink what?" for "What would you like to drink?"

In summary, dominant Vietnamese learners of English may have difficulty with sound, word, and grammatical aspects of English not found in Vietnamese. For instance, they may have difficulty producing consonant clusters, affricates, and syllable-final consonant sounds as well as using English intonation patterns due to the influence of lexical tone. They may have difficulty using English vocabulary that make lexicalsemantic distinctions not found in Vietnamese and they may depend on the sentence context (rather than morphology) to express and/or interpret words as different word classes. These learners may have difficulty producing English word inflections such as the past tense -ed as well as using English subject-verb inversion and auxiliary verbs when asking questions. 


\section{English Transfer to Vietnamese}

It is well known that a person's L1 may influence their L2 performance in adult L2 learners (e.g., McDonald, 2000; Sato, 1988). Recent studies have also shown that L2 skills may influence L1 performance (Hernandez, Bates, \& Avila, 1994; Su, 2001). Table 7 presents potential interaction of English with Vietnamese in Vietnamese American students learning both languages.

Table 7

Potential interactions of English (L2) with Vietnamese (L1)

\begin{tabular}{|c|c|c|}
\hline Lang. Level & Pattern & Example \\
\hline \multirow{8}{*}{$\begin{array}{l}\text { Phonology } \\
\text { (Sound } \\
\text { level) }\end{array}$} & Simplify 2-3 vowel combinations & Says phung for phuong \\
\hline & Substitute with English consonants & English " $\mathrm{k}$ " for Vietnamese " $\mathrm{kh}$ " \\
\hline & Substitute with English diphthongs & English "ou" for Vietnamese "o" \\
\hline & Aspiration of $/ \mathrm{p}, \mathrm{t}, \mathrm{k} /$ in initial or final & 1) $m \ddot{a} t^{h}$ for $m \ddot{a} t$ "eye" \\
\hline & positions & 2) English " $t$ " for Vietnamese \\
\hline & & $\begin{array}{l}\text { dental aspirated " } t \text { " as in tho } \\
\text { "rabbit" }\end{array}$ \\
\hline & Tone errors & Says $c u$ "penis" for $c u$ "owl" \\
\hline & Rising intonation added to questions & May affect tones and meaning \\
\hline \multirow{5}{*}{$\begin{array}{l}\text { Lexical } \\
\text { semantics } \\
\text { (Word } \\
\text { meaning) }\end{array}$} & $\begin{array}{l}\text { Difficulty using words that do not } \\
\text { have direct English translations }\end{array}$ & $\begin{array}{l}\text { mang, vác, khiêng, xách, bung } \\
\text { are translated as "to carry" in } \\
\text { English }\end{array}$ \\
\hline & Overgeneralization of classifiers & cái viết for cây viết "pen" \\
\hline & Omission of classifiers ${ }^{1}$ & $\begin{array}{l}\text { hai chó* for hai con chó "two } \\
\text { dogs" }\end{array}$ \\
\hline & Difficulty using kinship terms & $\begin{array}{l}\text { Refer to oneself as con "child" } \\
\text { when speaking to same-aged } \\
\text { peers }\end{array}$ \\
\hline & $\begin{array}{l}\text { Difficulty understanding } \\
\text { reduplications }\end{array}$ & \\
\hline \multirow{5}{*}{$\begin{array}{l}\text { Morpho- } \\
\text { Syntax } \\
\text { (Grammar) }\end{array}$} & Overuse of function words & $\begin{array}{l}\text { Use đã, đang, sẽ when not } \\
\text { needed }\end{array}$ \\
\hline & $\begin{array}{l}\text { Difficulty with word order for } \\
\text { possession }\end{array}$ & Mẹ xe for xe me \\
\hline & $\begin{array}{l}\text { Difficulty with word order in } \\
\text { questions }\end{array}$ & Đâu đi anh? for Anh đi đâu? \\
\hline & Omission of classifiers 1 & See above \\
\hline & Place adjectives before nouns & đẹp buóm for buóm đẹp \\
\hline
\end{tabular}

\footnotetext{
${ }^{1}$ Omission of classifiers may indicate a change in meaning (semantic) as well as a change in grammar. Therefore this potential interaction may be placed at the lexical-semantic level as well as the morphosyntactic level.
} 
Potential interactions of English (L2) with Vietnamese (L1), also known as negative transfer, often found in children whose L1 is a minority language and who may experience a relative shift in dominance to L2. These are predictions of negative transfer patterns based on a cross-linguistic analysis. Future empirical evidence is needed to refute or support these patterns. At the phonological (sound) level, the tone production of these students may be affected since tones do not have lexical meaning in English. Vietnamese students in an English language environment may have difficulty perceiving and/or producing tones correctly. Oftentimes, the older Vietnamese generation may be amused by their children's "American accent" and tease them for tonal errors that change lexical meaning. For instance, a child may want to say con cú "an owl" but may drop the rising (sắc) tone and say con cu "penis." A related difficulty is the influence of English intonation patterns. In English many questions are asked with a rising intonation at the end of the sentence. Students who are acquiring both languages may have a rising intonation in Vietnamese, which alters tones and may affect meaning or intelligibility.

In regards to sound-substitution, the Vietnamese aspirated dental " $\mathrm{t}$ " as in tho "rabbit" and the velar fricative "kh" as in không "no" may be produced as an English " $\mathrm{t}$ " and "k," respectively. In addition, Vietnamese final consonant sounds, which are typically unreleased (Dinh \& Nguyen, 1998), may be produced with some aspiration (or at least an audible release) since English final consonants can be released (Harris, 1994). Vietnamese single vowels may become elongated or diphthongized, such as with the vowel /o/ being produced as the English diphthong /ov/. Vietnamese two- or three-vowel combinations may be simplified due to the relatively few number of vowel combinations in English (see Table 2).

Vietnamese American students acquiring both languages may also make errors at the lexical-semantic (word) level. For instance, there are many Vietnamese words that have multiple-to-one mappings into English; an English verb can have multiple Vietnamese correlates that are attached to specific contexts. For example, the English verb "to carry" corresponds to Vietnamese verbs mang "to carry a general object," vác "to carry on one's back," khiêng "to carry a heavy object," bồng bé "to carry [a child] on the side of one's hip," xách "to carry an object with a handle," and bung "to carry with both hands and in front of one's body." The English verb "to wear" corresponds to Vietnamese verbs mạc "to wear in general," mang "to wear socks/shoes," đeo "to wear glasses/jewelry/wristwatch," and độ "to wear an object on one's head." The English verb "to give" corresponds to Vietnamese verbs đua "to give with one hand," cho "to give to someone of your status or younger," tạng "to give to someone who is slightly higher in status," and biếu "to give to someone who is much higher in status or age / to give with great respect." One influence of English on Vietnamese would be the overuse of the general verbs or the incorrect use of specific context-based verbs.

Another area of potential English influence is the misuse or simplifications of classifiers (see the lexical-semantic subsection for details on classifiers). Vietnamese American students may tend to overuse the general classifier for inanimates, cái, with nouns that require more specific classifiers (H. A. Nguyen, personal communication, March 12, 2006). For instance, a student may say cái viết for "a pen" instead of cây viết; cây indicates a long thin object, which is more specific than cái. Since there are no classifiers in English, another potential interaction may be the omission of Vietnamese classifiers in required contexts. For instance, a child may omit the animate classifier, con, 
in hai con chó [two cl-animate dog] "two dogs" and incorrectly say hai chó [two dog]. This error pattern may indicate a change in meaning as well as a change in grammar.

Another lexical-semantic feature that occurs far more frequently in Vietnamese than English is reduplication (see lexical-semantic subsection for details). Vietnamese American students may not be exposed to many examples of reduplication and may not comprehend their meaning or may not use this feature in spoken language. There has been little to no research documenting the frequency and distribution of reduplications in the language use of parents or in children's literature. Therefore it is unclear how children acquiring both languages would interpret and use this language feature.

The final lexical-semantic feature discussed in this section is related to the use of pronouns. Vietnamese uses many kinship terms as pronouns (see lexical-semantic subsection for details). As discussed in the lexical semantics section, kinship terms are used in with everyone, not only direct family members. Vietnamese children in the United States may not have extended relatives as they typically would in Vietnam and therefore may have limited opportunity to use a variety of kinship terms such as ong "grandfather," bà "grandmother" chú "uncle or father's younger brother," dì "aunt or mother's younger sister," and bác "aunt or mother or father's older sister." Limited exposure and practice with kinship terms may affect how children use Vietnamese pronouns in social contexts with interlocutors of varying age and status (Luong, 1990). In addition, Vietnamese American students may have difficulty adjusting personal reference when referring to themselves. For instance, given a listener of a specific gender and age, they may need to use a variety of kinship terms such as cháu "niece/nephew," con "son/daughter," em "younger sibling," chị "older sister," and ban "friend." Children who speak Vietnamese only to their parents may make the mistake of referring to themselves as con "son/daughter" when meeting new same-aged peers.

In regards to the morpho-syntactic (grammatical) level, Vietnamese influences on English (L2) may involve word order. Vietnamese American students may place adjectives before nouns such as đẹp buóm [pretty butterfly] for buóm đẹp [butterfly pretty] "pretty butterfly." To indicate possession, they may place the possessor in front of the possession such as me xe [mother car] for xe me [car mother] "mother's car." They may use English subject-verb inversion in constructing Vietnamese questions or may have difficulty knowing where to place the question word (see Table 5 for examples). In addition, they may omit classifiers that are required to complete a noun phrase (see Tables 5 and 6 for examples).

In summary, English skills may influence Vietnamese performance in Vietnamese American students across the sound, word, and grammatical levels. For instance, children may have difficulty with consonant and vowel sounds not shared in English (see tables 1 and 2) as well as misuse or omit lexical tone. At the word level, children may have difficulty using Vietnamese vocabulary that have lexical-semantic distinctions not found in English as well as L1-specific word types such as classifiers, kinship terms, and reduplications. At the grammatical level, children may use English word order when producing adjectives, possessives, and questions in Vietnamese.

Another potential cross-linguistic interaction not previously discussed is related to code-switching, operationally defined as the use of words, phrases, or sentences from both languages in a conversation. Petito et al. (2001) found that parents who codeswitched had children who code-switched at similar rates. It should be noted that code- 
switching has been demonstrated in research to be a common and legitimate mode of bilingual communication that follows syntactic structure and has specific functions in conversation (Myers Scotton, 1988; Poplack, 1980). Poplack (1980) found the use of code-switching in "balanced" bilinguals (i.e., fluent in both languages) as well as groups who identified themselves as L1 dominant. Therefore, Vietnamese parents who have arrived in the United States as adults and remain dominant in their L1 still may exhibit English code-switches in their language use, which in turn may be reflected in the language use of their children. The next generation of parents may differ from the current generation in that most parents will have been educated in the United States and have greater familiarity with English. There has been no research on the affects or influence of the language input provided by Vietnamese parents who are fluent in both languages, or perhaps English-dominant, on the language use of their children. Questions such as "what are code-switching behaviors in adult bilinguals?" and "how is that reflected in the language output of children?" may be important to investigate as it pertains to current and future generations of Vietnamese Americans.

\section{Conclusions and Implications for Future Research}

Research studies on the three-generation model have found a rapid language shift in relative dominance from L1 to English (L2) among immigrant populations (Fishman, 1972; Veltman, 1983). Numerous studies have indicated social and academic advantages of bilingualism such as strong social connections within the family and ethnic community (Kohnert \& Derr, 2004; Wong-Fillmore, 1991), a strong social identification (Zhou \& Bankston, 1998), and the transmission of traditional values such as the importance of education (Zhou \& Bankston, 1994). The social issues surrounding the subject of language maintenance impress on us the immediate need to find and promote methods of L1 maintenance during the development of L2.

This paper has focused on L1 maintenance and language shift towards L2 among Vietnamese Americans. Studies on across generation language shift in Vietnamese American youth have suggested that this population is undergoing a rapid shift towards English monolingualism as described by the three-generation model (Young \& Tran, 1999). Although there have been studies regarding L1 influences on L2 performance in Vietnamese adults (e.g., McDonald, 2000; Sato, 1988) as well as studies that examine L1-L2 interactions in bilingual populations of other languages (e.g. Hernandez, Bates, Avila, 1994; Kan \& Kohnert, 2005; Kohnert, 2002; Kohnert \& Bates, 2002; Kohnert, Bates, \& Hernandez, 1999; Su, 2001) there have been little to no studies on crosslinguistic interactions in Vietnamese American children. This paper is an initial step of making predictions about language interactions between Vietnamese and English based on a cross-linguistic comparison at phonological (sound), lexical-semantic (word meaning), and morpho-syntactic (grammatical) levels. Empirical evidence is necessary to support or refute the observations presented in this article.

The fields of child language acquisition and bilingualism may provide a framework for future empirical investigation. In a recent workshop sponsored by the United States Department of Education and the United States Department of Health and Human Services (Childhood Bilingualism, 2005), the following questions were proposed to shape the future direction of research: How does the first language influence the 
second language? How does the second language affect continued development of the first? How and when does (or should) the second language get reinforced?

Quantitative information regarding the frequency and distribution of speech sounds and words of Vietnamese based on both oral language samples and written texts are needed to establish how rare or common linguistic features are and therefore how often they occur in daily language use. Language materials and experimental stimuli may be created based on linguistic information presented in this article as well as frequency and distributional information from large corpora in Vietnamese. Both cross-sectional and longitudinal studies are needed to investigate the language development of Vietnamese children in the United States who are exposed to English at an early age. This line of research may provide useful information regarding cross-language transfer of skills and within-language development, which may contribute to a better overall understanding of how children learn two languages. A clear understanding of normal variation in the language development of children exposed to two languages is the first step in developing effective language teaching materials as well as assessment and educational interventions for a variety of language learners. Research in this area may be applied to language instruction materials and strategies to promote L1 maintenance along with L2 development in the home and school environments.

\section{References}

Adams, K. L. (1989). Systems of numeral classification in the Mon-Khmer, Nicobarese and Asian subfamilies of Austroasiatic. Canberra, Australia: Pacific Linguistics Series B-101.

Alba, R., Logan, J., Lutz, A., \& Stults, B. (2002). Only English by the third generation? Loss and preservation of the mother tongue among the grandchildren of contemporary immigrants. Demography, 39(3), 467-484.

Aikhenvald, A. Y. (2000). Classifiers: A typology of noun categorization devices. Oxford, UK: Oxford University Press.

Alves, M. J. (1999). What's so Chinese about Vietnamese? In G. Thurgood (Ed.), Papers from the ninth annual meeting of the Southeast Asian Linguistics Society (pp. 221242). Berkeley, CA: University of California.

The American heritage dictionary (4th ed.). (2000). Boston: Houghton Mifflin Company.

Anderson, R. (2004). First language loss in Spanish-speaking children: Patterns of loss and implications for clinical practice. In B. A. Goldstein (Ed.), Bilingual language development and disorders in Spanish-English speakers (pp. 187-211). Baltimore, MD: Paul Brookes Publishing Co., Inc.

Bankston, C. L., III, \& Zhou, M. (1995). Effects of minority-language literacy on the academic achievement of Vietnamese youths in New Orleans. Sociology of Education, 68(1), 1-17.

Bauer, L. (1983). English word-formation. Cambridge, UK: Cambridge University Press.

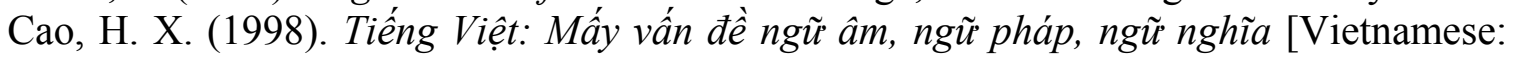
issues in phonetics, syntax, and semantics]. Ho Chi Minh City, Vietnam: Nhà Xuất Bản Giáo Dục. 
Cao, X. H. (2004). Âm vị học và tuyến tính: Suy nghĩ về các định đề của âm vị học đương đại [Phonology and linearity: Critique of contemporary phonology postulations, 2nd ed.]. Hà Nội, Vietnam: Nhà Xuất Bản Đại Học Quốc Gia.

Chung, C. (2000). English language learners of Vietnamese background. In S. L. McKay \& S. C. Wong, (Eds.), New immigrants in the United States (pp. 216-231). New York: Cambridge University Press.

Daley, K. A. (1998). Vietnamese classifiers in narrative texts. Dallas, TX: Summer Institute of Linguistics, Inc.

Đánh vần mau [Spell quickly]. (n.d.). (author and publisher unknown).

Dinh, T. L. \& Nguyen, H. V. (1998). Cơ cấu ngũ âm tiếng Việt [Structure of Vietnamese phonetics]. Ho Chi Minh City, Vietnam: Nhà Xuất Bản Giáo Dục.

Do, C. H. (1981). Tù vưng ngũu nghĩa tiếng Việt [Vietnamese lexico-semantics]. Hanoi, Vietnam: Nhà Xuất Bản Giáo Dục.

Doan, T. T. (1999). Ngũ âm tiếng Việt. [Vietnamese phonetics]. Hà Nội, Vietnam: Nhà Xuất Bản Đại Học Quốc Gia Hà Nội.

Erickson, J. (2001). English. In J. Garry \& C. Rubino (Eds.), Facts about the world's languages: An encyclopedia of the world's major languages, past, and present (pp. 199-203). New York: H. W. Wilson Company.

Feliciano, C. (2001). The benefits of biculturalism: Exposure to immigrant culture and dropping out of school among Asian and Latino youths. Social Science Quarterly, $82,865-879$.

Fishman, J. (1972). The Sociology of Language. Rowley, MA: Newbury.

Flege, J. E., Yeni-Komshian, G. H., \& Liu, S. (1999). Age constraints on secondlanguage acquisition. Journal of Memory and Language, 41, 78-104.

Genesee, F., Paradis, J., \& Crago, M. (2004). Dual language development and disorders: $A$ handbook on bilingualism and second language learning. Baltimore, MD: Paul H. Brooks Publishing Company.

Harris, I. (1994). English sound structure. Oxford, UK: Blackwell Publishers.

Hernandez, A., Bates, E. \& Avila, L. (1994). On-line sentence interpretation in SpanishEnglish bilinguals: What does it mean to be "in between"? Applied Psycholinguistics, 15, 417-446.

Jakobson, R. (1968). Child language, aphasia and phonological universals. The Hague, Netherlands: Mouton.

Kan, P. F. and Kohnert, K. J. (2005). Preschoolers learning Hmong and English: Lexicalsemantic skills in L1 and L2. Journal of Speech, Language, and Hearing Research, 48, 372-383.

Kohnert, K. (2002). Picture naming in early sequential bilinguals: A 1-year follow-up. Journal of Speech, Language, and Hearing Research, 45, 759-771.

Kohnert, K., \& Bates, E. (2002). Balancing bilinguals II: Lexical comprehension and cognitive processing in children learning Spanish and English. Journal of Speech, Language, and Hearing Research, 45, 347-359.

Kohnert, K., Bates, E., \& Hernandez, A. (1999). Balancing bilinguals: Lexical-semantic production and cognitive processing in children learning Spanish and English. Journal of Speech, Language, and Hearing Research, 42, 1400-1413.

Kohnert, K. \& Derr, A. (2004). Language intervention with bilingual children. In B. Goldstein (Ed.), Bilingual language development and disorders in Spanish- 
English speakers (pp. 311-338). Baltimore, MD: Paul H. Brooks Publishing Company.

Kreidler, C. W. (1998). Introducing English semantics. London: Routledge.

Luong, H. V. (1990). Discursive practices and linguistic meanings: The Vietnamese system of person reference. Philadelphia, PA: John Benjamins Publishing Company.

McDonald, J. L. (2000). Grammaticality judgments in a second language: Influences of age of acquisition and native language. Applied Psycholinguistics, 21, 395-423.

Myers Scotten, C. (1988). Code switching as indexical of social negotiations. In M. Heller (Ed.), Codeswitching: Anthropological and sociolinguistic perspectives (pp. 151-186). Berlin: Mouton de Gruyter.

Nelson, K. (1995). The dual category program in acquisition of action words. In M. Tomasello, W. E. Merriman (Eds.), Beyond names for things: Young children's acquisition of verbs (pp. 223-250). Mahwah, NJ: Lawrence Erlbaum Associates.

Nguyen, C. T. (1999). Ngũu pháp tiếng Việt, in lần thư sáu [Vietnamese grammar, $6^{\text {th }}$ edition]. Hà Nội, Vietnam: Nhà Xuất Bản Đại Học Quốc Gia.

Nguyen, D. H. (1996). Vietnamese verbs. Mon-Khmer Studies 25, 141-159.

Nguyen, D. H. (1997). Vietnamese. Amsterdam: John Benjamins Publishing Company.

Nguyen, D. H. (2001). Vietnamese. In J. Garry \& C. Rubino (Eds.), Facts about the world's languages: An encyclopedia of the world's major languages, past, and present (pp. 794-796). New York: The H. W. Wilson Company.

Nguyen, D. L. (1970a). A contrastive grammatical analysis of English and Vietnamese. In D. L. Nguyen (Ed.), A contrastive analysis of English and Vietnamese: Vol. 3. Sydney, Australia: Pacific Linguistics.

Nguyen, D. L. (1970b). A contrastive phonological analysis of English and Vietnamese. In D. L. Nguyen (Ed.), A contrastive analysis of English and Vietnamese: Vol. 4. Sydney, Australia: Pacific Linguistics.

Nguyen, G. T. (2003). Tù vựng học tiếng Việt, tài bản lần thư tur [Vietnamese lexicography, $4^{\text {th }}$ edition]. Ho Chi Minh City, Vietnam: Nhà Xuất Bản Giáo Dục.

Nguyen, H. V. (2003). Tù Điển Ngũu Pháp Tiếng Việt Co Bản - Dictionary of Basic Vietnamese Grammar: Bilingual Vietnamese-English. Ho Chi Minh City, Vietnam: Nhà Xuất Bản Đại Học Quốc Gia.

Nguyen, K. L. (2004). Giáo trình tiếng Việt II [Vietnamese textbook II]. Huế, Vietnam: Đại Học Huế Trung Tâm Tạo Từ Xa.

Nguyen, A., Shin, F., \& Krashen, S. (2001). Development of the first language is not a barrier to second-language acquisition: Evidence from Vietnamese immigrants to the United States. International Journal of Bilingual Education and Bilingualism, 4(3), 159-164.

Petito, P., Katerelos, M., Levy, B. G., Gauna, K., Tétreault, K., \& Ferraro, V. (2001). Bilingual signed and spoken language acquisition from birth: Implications for the mechanisms underlying early bilingual language acquisition. Journal of Child Language, 28, 453-496.

Pham, L. (1990). Functional patterns in infant bilingualism: A case study of the simultaneous acquisition of two languages by a three-year-old VietnameseAmerican child. Unpublished doctoral dissertation, University of Houston. 
Poplack, S. (1980). Sometimes I'll start a sentence in Spanish y termino en español: toward a typology of code-switching. Linguistics, 18, 581-618.

Quirk, R., Greenbaum, S., Leech, G., Svartvik, J. (1989). A comprehensive grammar of the English language. London: Longman Inc.

Reeves, T. J. \& Bennett, C. E. (Dec, 2004). We the people: Asians in the United States. Census 2000 Special Reports. Washington, DC: United States Department of Commerce Economics and Statistics Administration. (United States Census Bureau Report No. ASI 2004 2326-31.16)

Riney, T. J. (1988). The interlanguage phonology of Vietnamese English. Unpublished doctoral dissertation, Georgetown University.

Rumbaut, R. (1995). The new Californians: Comparative research findings on the educational progress of immigrant children. In R. Rumbaut \& W. A. Cornelius (Eds.), California's immigrant children: Theory, research, and implications for educational policy (pp. 17-70). San Diego, CA: Center for United States Mexican Studies.

Sato, C. J. (1988). Origins of complex syntax in interlanguage development. Studies in Second Language Acquisition, 10, 371-395.

Schmid, C. L. (2001). Educational achievment, language-minority students, and the new second generation. Sociology of Education (Extra Issue), 71-87.

Stanton-Salazar, R. D. \& Dornbusch, S. M. (1995). Social capital and the reproduction of inequality: Information networks among Mexican-origin high school students. Sociology of Education, 68, 116-135.

Stubbs, M. (2001). Words and phrases: Corpus studies of lexical semantics. Oxford, UK: Blackwell Publishers, Inc.

$\mathrm{Su}$, I. (2001). Transfer of sentence processing strategies: A comparison of L2 learners of Chinese and English. Applied Psycholinguistics, 22, 83-112.

Tang, G. \& Barlow, J. (2006). Characteristics of sound systems of monolingual Vietnamese-speaking children with phonological impairment. Clinical Linguistics \& Phonetics, 20(6), 423-445.

Thompson, L. (1965). A Vietnamese Grammar. Seattle, WA: University of Washington Press.

Trung tâm khoa học xã hội và nhân văn: Quốc gia viện ngôn ngữ học [Center of Natural and Social Sciences: National Institute of Linguistics]. (2000). Loại tù trong các

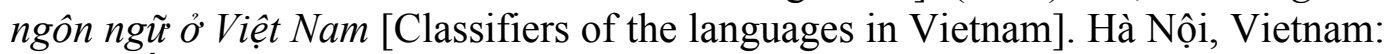
Nhà Xuất Bản Khoa Học Xã Hội.

United States Department of Education and United States Department of Health and Human Services. (2005, Jan). Childhood bilingualism: Current status and future directions. Retrieved April 5, 2006, from http://www.nichd.nih.gov/about $\% 5 \mathrm{Ccrmc} / \mathrm{cdb} / \mathrm{p}$ lang.htm

Veltman, C. (1983). Language shift in the United States. Berlin: Mouton de Gruyter.

Wong-Fillmore, L. (1991). When learning a second language means losing the first. Early Childhood Research Quarterly, 6, 323-346.

Young, R. \& Tran, M. (1999). Language maintenance and shift among Vietnamese in America. International Journal of the Sociology of Language, 140, 77-82.

Zhou, M. \& Bankston, C. L., III. (1994). Social capital and the adaptation of the second 
generation: The case of Vietnamese youth in New Orleans. International Migration Review, 28(4), 821-845.

Zhou, M. \& Banskton, C. L., III. (1998). Growing up American. New York: Russell Sage

Foundation.

Zhou, M. \& Bankston, C. L., III. (2000). Straddling two social worlds: The experience of Vietnamese refugee children in the United States. Washington, DC: ERIC Clearinghouse on Urban Education. (ERIC Document Reproduction Service No. ED-99-CO-0035)

\section{Acknowledgements}

Portions of this paper were presented at the joint conference of the National Association for Asian and Pacific American Education and the National Association for the Education and Advancement of Cambodian, Laotian, and Vietnamese Americans, co-sponsored by the National Education Association. The Bryn Bryngelson Research Fund and the College of Liberal Arts at the University of Minnesota provided funding for travel expenses related to the conference presentation on which this paper is based. I would like to thank Jessica Barlow and Kathryn Kohnert for reviewing earlier drafts of this paper as well as Hai Anh Nguyen, Pui Fong Kan, Kelly Nett Cordero, Jy Xiong, and Brenna Vaughn for helpful suggestions and comments.

Please address correspondence to Giang Tang in the Department of SpeechLanguage-Hearing Sciences, 115 Shevlin Hall, 164 Pillsbury Drive S.E., University of Minnesota, Minneapolis, MN 55455 or via email at tangx098@umn.edu.

\section{About the Author}

Tăng Ngọc Thùy Giang is currently a doctoral student in the Department of SpeechLanguage-Hearing Sciences at the University of Minnesota. She completed a BA in Spanish and a BS in Speech, Language, and Hearing Sciences at the University of Illinois and a MA in Speech-Language Pathology as well as a certificate of Bilingual SpeechLanguage Pathology from San Diego State University. Giang has worked as a bilingual speech-language pathologist in preschool and elementary school settings with students who speak Spanish as a home language. In addition to serving Latino populations, she has volunteered in Vietnam on multiple occasions training special educators and families of individuals with disabilities. Giang is a fluent speaker of English, Vietnamese, and Spanish. As a doctoral student, she aims to investigate typical and atypical language development in dual-language learners, particularly in Vietnamese-speaking populations. 


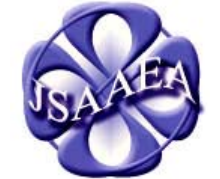

Volume 2

\section{Journal of Southeast Asian American Education \& Advancement WWW.JSAAEA.org}

A peer-reviewed scholarly journal published by the National Association for the Education \& Advancement of Cambodian, Laotian, and Vietnamese Americans (NAFEA)

\section{Editor}

Dr. Wayne E. Wright

University of Texas, San Antonio

\section{Associate Editors}

Dr. Chhany Sak-Humphry

University of Hawaii

Dr. KimOanh Nguyen-Lam

California State University, Long Beach

Book Review Editor

Dr. Leslie Turpin

School for International Training

\section{Creative Works Editor}

Phouang Hamilton

Washington Office of Superintendent of Public Instruction

\section{Special Advisor}

Anne Frank

University of California, Irvine, Southeast Asian Archives

\section{Editorial Assistant}

James Knaack

University of Texas, San Antonio

Comments and questions for the editorial staff may be directed to jsaaea@lists.sis.utsa.edu.

\section{Editorial Review Board}

\author{
Dr. Carl L. Bankston III \\ Tulane University \\ Dr. Pollie Bith-Melander \\ San Jose State University \\ Dr. Phala Chea \\ Lowell Public Schools \\ Dr. George Chigas \\ University of Massachusetts, Lowell
}

\author{
Dr. Changming Duan \\ University of Missouri, Kansas City \\ Dr. Sophal Ear \\ Syracuse University
}

Dr. Nancy H. Hornberger

University of Pennsylvania

Dr. Samlong Inthaly

Minneapolis Public Schools 
Tang: Cross-Linguistic Analysis of Vietnamese and English with Implicat

Tang - Cross-linguistic Analysis of Vietnamese and English

\begin{tabular}{|c|c|}
\hline $\begin{array}{c}\text { Dr. Peter Nien-Chu Kiang } \\
\text { University of Massachusetts, Boston }\end{array}$ & $\begin{array}{c}\text { Dr. Karen Quintiliani } \\
\text { California State University, Long Beach }\end{array}$ \\
\hline $\begin{array}{l}\text { Dr. Kevin K. Kumashiro } \\
\text { University of Illinois, Chicago }\end{array}$ & $\begin{array}{c}\text { Dr. Kalyani Rai } \\
\text { University of Wisconsin, Milwaukee }\end{array}$ \\
\hline $\begin{array}{c}\text { Dr. Stacey Lee } \\
\text { University of Wisconsin, Madison }\end{array}$ & $\begin{array}{c}\text { Dr. Fay Shin } \\
\text { California State University, Long Beach }\end{array}$ \\
\hline $\begin{array}{l}\text { Dr. David Chanpannha Ley } \\
\text { Montgomery County Public Schools }\end{array}$ & $\begin{array}{l}\text { Dr. Nancy J. Smith-Hefner } \\
\text { Boston University }\end{array}$ \\
\hline $\begin{array}{l}\text { Dr. Sue Needham } \\
\text { California State University, Dominguez Hills }\end{array}$ & $\begin{array}{l}\text { Dr. Yer J. Thao } \\
\text { Portland State University }\end{array}$ \\
\hline $\begin{array}{c}\text { Dr. Bic Ngo } \\
\text { University of Wisconsin-Madison }\end{array}$ & $\begin{array}{c}\text { Dr. Myluong Tran } \\
\text { San Diego State University }\end{array}$ \\
\hline $\begin{array}{l}\text { Dr. Max Niedzwiecki } \\
\text { Independent Scholar }\end{array}$ & $\begin{array}{c}\text { Dr. Khatharya Um } \\
\text { University of California, Berkeley }\end{array}$ \\
\hline $\begin{array}{l}\text { Dr. Leakhena Nou } \\
\text { California State University, Long Beach }\end{array}$ & $\begin{array}{l}\text { Dr. Linda Trinh Vo } \\
\text { University of California, Irvine }\end{array}$ \\
\hline $\begin{array}{c}\text { Dr. Clara Park } \\
\text { California State University, Northridge }\end{array}$ & $\begin{array}{l}\text { Dr. Terrence G. Wiley } \\
\text { Arizona State University }\end{array}$ \\
\hline $\begin{array}{c}\text { Dr. Mark Pfeifer } \\
\text { Texas A\&M University, Corpus Christi }\end{array}$ & $\begin{array}{l}\text { Dr. Zha Blong Xiong } \\
\text { University of Minnesota }\end{array}$ \\
\hline $\begin{array}{l}\text { Dr. Loan T. Phan } \\
\text { University of New Hampsire }\end{array}$ & $\begin{array}{c}\text { Dr. Kou Yang } \\
\text { California State University, Stanislaus }\end{array}$ \\
\hline
\end{tabular}

Dr. Bounlieng Phommasouvanh

Minnesota Department of Education

\title{
Doctoral Student \\ Editorial Review Board
}

\author{
Keo Chea \\ University of Pennsylvania \\ Vichet Chhuon \\ University of California, Santa Barbara \\ Loan Dao \\ University of California, Berkeley \\ Annie BichLoan Duong \\ San Joaquin County Office of Education \\ Ha Lam \\ Arizona State University \\ Vanna Som \\ Harvard University
}

\author{
Giang Tang \\ University of Minnesota \\ Layheng Ting \\ State University of New York, Albany \\ Loan Tran \\ University of California, Santa Barbara \\ Phitsamay Sychitkokhong Uy \\ University of California, Los Angeles
Harvard University
Yang Sao Xiong

